\title{
Impact of biomass burning and stratospheric intrusions in the remote South Pacific Ocean troposphere
}

Nikos Daskalakis ${ }^{1}$, Laura Gallardo ${ }^{2}$, Maria Kanakidou ${ }^{1,3,4}$, Rasmus Nüß ${ }^{1}$, Camilo Menares ${ }^{2}$, Roberto Rondanelli $^{2}$, Anne M. Thompson ${ }^{5}$, Mihalis Vrekoussis ${ }^{1,6,7}$

5 'Laboratory for Modeling and Observation of the Earth System (LAMOS), Institute of Environmental Physics (IUP), University of Bremen, Bremen, Germany

${ }^{2}$ Center for Climate and Resilience Research (CR2) \& Department of Geophysics, Faculty of Physical and Mathematical Sciences, University of Chile, Santiago, Chile

10 Greece

${ }^{3}$ Environmental Chemical Processes Laboratory (ECPL), Department of Chemistry, University of Crete, 70013 Heraklion,

${ }^{4}$ CSTACC, ICE-HT, FORTH, Patras, Greece

${ }^{5}$ NASA Goddard Space Flight Center, Greenbelt, Maryland 20771, USA

${ }^{6}$ Center of Marine Environmental Sciences (MARUM), University of Bremen, Germany

15

${ }^{7}$ Climate and Atmosphere Research Center (CARE-C), The Cyprus Institute, Cyprus

Correspondence to: Nikos Daskalakis (daskalakis@uni-bremen.de)

Abstract. The ozone mixing ratio spatio-temporal variability in the pristine southern Pacific Ocean is studied, for the first time, using 21-year long ozone $\left(\mathrm{O}_{3}\right)$ records from the entire southern tropical and subtropical Pacific, between 1994 and 2014. The analysis considered regional $\mathrm{O}_{3}$ vertical observations from ozonesondes, surface carbon monoxide (CO) observations

20 from flasks and three-dimensional chemistry-transport model simulations of the global troposphere. Two 21-year long numerical simulations, with and without biomass burning emissions, were performed to disentangle the importance of biomass burning relative to stratospheric intrusions for ambient ozone levels in the region. Tagged tracers of $\mathrm{O}_{3}$ from the stratosphere and $\mathrm{CO}$ from various biomass burning regions have been used to track the impact of these different regions on the southern tropical Pacific $\mathrm{O}_{3}$ and $\mathrm{CO}$ levels. Patterns have been analyzed based on atmospheric dynamics variability.

25 Considering the interannual variability in the observations, the model can capture the observed ozone gradients in the troposphere with a positive bias of $7.5 \%$ in the upper troposphere/low stratosphere (UTLS), as well as near the surface. Remarkably, even the most pristine region of the global ocean is affected by distant biomass burning emissions by convective outflow through the mid and high troposphere and subsequent subsidence over the pristine oceanic region. Therefore, the biomass burning contribution to tropospheric CO levels maximizes in the UTLS. The Southeast Asian open fires have been identified as the major contributing source to $\mathrm{CO}$ from biomass burning in the tropical southern Pacific, contributing on average for the study period about 8.5 and $13 \mathrm{ppb}_{\mathrm{v}}$ of $\mathrm{CO}$ at Rapa Nui and Samoa, respectively, at an altitude of around $12 \mathrm{~km}$ during the burning season in the spring of the Southern Hemisphere. South America is the second most important biomass burning source region that influences the study area. Its impact maximizes in the lower troposphere ( $6.5 \mathrm{ppb}_{\mathrm{v}}$ for Rapa Nui and 3.8 $\mathrm{ppb}_{\mathrm{v}}$ for Samoa). All biomass burning sources contribute about 15-23 $\mathrm{ppb}_{\mathrm{v}}$ of $\mathrm{CO}$, accounting for about $25 \%$ of the total CO 
35 in the entire troposphere of the tropical and subtropical South Pacific. This impact is also seen on tropospheric $\mathrm{O}_{3}$, to which biomass burning $\mathrm{O}_{3}$ precursor emissions contribute only a few $\mathrm{ppb}_{\mathrm{v}}$ during the burning period, while the stratospheretroposphere exchange is the most important source of $\mathrm{O}_{3}$ for the mid-troposphere of the south Pacific Ocean, contributing about $15-20 \mathrm{ppb}_{\mathrm{v}}$ in the subtropics.

\section{Introduction}

40 Ozone $\left(\mathrm{O}_{3}\right)$ is one of the major and most abundant oxidants in the Earth's atmosphere and a driver of tropospheric chemistry (Monks et al., 2015). Due to its oxidative power, $\mathrm{O}_{3}$ is also toxic for ecosystems and affects human health (Fleming et al., 2018; Jerrett et al., 2009; Mills et al., 2018; Pöschl \& Shiraiwa, 2015). Tropospheric $\mathrm{O}_{3}$ is itself a greenhouse gas, capturing part of the Earth's outgoing longwave radiation, thus warming the atmosphere (Bowman et al., 2013; Lacis et al., 1990); and contributing by about $25 \%$ to the greenhouse gas forcing due to human activities (Monks et al., 2009; Myhre et al., 2013). The radiative forcing (RF) of $\mathrm{O}_{3}$ has been calculated based on the Climate Model Intercomparison Project phase 6 (CMIP6) simulations to be $0.28 \pm 0.17 \mathrm{~W} \mathrm{~m}^{-2}$ for the period $1850-2000$ (Checa-Garcia et al., 2018). This value is considerably higher (about 80\%) than the previous Climate Model Intercomparison Project (CMIP5) estimates (Stevenson et al., 2013). Moreover, it was found that the RF of tropospheric $\mathrm{O}_{3}$ maximizes near the tropopause (Lacis et al., 1990; Monks et al., 2015; Stevenson et al., 2013). Both the outgoing longwave radiation and the contribution of $\mathrm{O}_{3}$ to this emission of radiation maximize over the tropics, which, due to their location, are also receiving most of the solar radiation (Charlson, 2000; Stevenson et al., 2013). Therefore, to improve climate change projections, it is important to understand and simulate the tropospheric $\mathrm{O}_{3}$ behavior and sources over the tropical oceans, including the tropical south Pacific Ocean, which is considered the most pristine remaining marine environment.

Ozone is a secondary pollutant with no primary sources in the atmosphere. Tropospheric $\mathrm{O}_{3}$ changes have been mainly

55 attributed to changes in $\mathrm{O}_{3}$ precursor emissions and atmospheric dynamics, including stratosphere-troposphere exchanges (STE) (Stevenson et al., 2013; Sudo \& Akimoto, 2007). The contribution of precursor emissions to the calculated $\mathrm{O}_{3}$ forcing has been evaluated at $44 \pm 12 \%$ for methane $\left(\mathrm{CH}_{4}\right), 31 \pm 9 \%$ for nitrogen oxides $\left(\mathrm{NO}_{\mathrm{x}}=\mathrm{NO}+\mathrm{NO}_{2}\right), 15 \pm 3 \%$ for carbon monoxide (CO) and 9 $\pm 2 \%$ for non-methane volatile organic compounds (NMVOCs) emissions (Stevenson et al., 2013).

Sudo and Akimoto (2007) used tagged tracers for $\mathrm{O}_{3}$ to conclude that the STE of $\mathrm{O}_{3}$ contributes about $23 \%$ to the global net

60 source of tropospheric $\mathrm{O}_{3}$; the remaining $77 \%$ is controlled by photochemistry in the troposphere with the remote and the polluted regions contributing $29 \%$ and $48 \%$ of the global net source of tropospheric $\mathrm{O}_{3}$, respectively. Reanalysis data from the European Centre for Medium-Range Weather Forecasts (ECMWF) for the period 1979-2011, i.e., ERA-interim, have shown that the downward flux from the stratosphere to the troposphere has increased in the past three decades (Škerlak et al., 2014). They also show that the downward $\mathrm{O}_{3}$ flux maximizes in summer of each hemisphere, and STE reaching the boundary layer is 65 maximum in spring. Projections for 2100 estimate a 53\% increase of the influx of stratospheric $\mathrm{O}_{3}$ into the troposphere since 2000 under the Representative Concentration Pathway of $8.5 \mathrm{~W} / \mathrm{m}^{2}$ forcing (RCP 8.5) scenario, and a smaller change (about 
$42 \%$ ) under the moderate RCP6.0 emission scenario (Meul et al., 2018). However, the relative contribution of the STE to the tropospheric $\mathrm{O}_{3}$ levels is similar for both emission scenarios due to the resulting changes in $\mathrm{O}_{3}$ production. The projected increasing trend in $\mathrm{STE} \mathrm{O}_{3}$ flux has been attributed to decreasing levels in $\mathrm{O}_{3}$ depleting substances (ODS), affecting stratospheric $\mathrm{O}_{3}$ levels, and to increasing greenhouse gas concentrations that intensify stratospheric circulation and affect chemistry through changes in temperature and water vapor levels (Meul et al., 2018). The change in $\mathrm{STE} \mathrm{O}_{3}$ flux due to the ODS impact is stronger in the Southern Hemisphere ( $\mathrm{SH}$ ) than in the Northern Hemisphere (NH), while that due to greenhouse gas (GHG) effect is higher in the NH than in the SH. For the period 2000-2100, the STE contribution to $\mathrm{O}_{3}$ level changes in the SH has been estimated to be less than $40 \%$ during austral summer (Meul et al., 2018). During austral winter, climate change and the increase in stratospheric $\mathrm{O}_{3}$ and its influx to the troposphere contribute almost equally to the surface $\mathrm{O}_{3}$ increase $(\mathrm{G}$ Zeng et al., 2010).

Large-scale irregular-period variabilities in the atmospheric circulation and sea-surface temperatures and precipitation patterns like the El Niño-Southern Oscillation (ENSO) and the quasi-biennial oscillation (QBO) have been shown to affect tropospheric $\mathrm{O}_{3}$ amounts and variability (Logan et al., 2008). QBO additionally influences the Madden-Julian Oscillation (MJO), which

80 induces changes in altitude of the subtropical tropopause affecting STE and deep convection areas (Nishimoto \& Yoden, 2017; Sun et al., 2014; Young et al., 2018).

Multiple studies have addressed the impact of dynamical variability modes, mainly ENSO, on ozone and other atmospheric tracers in the tropical Pacific (Ebojie et al., 2016; Huang et al., 2014; Inness et al., 2015; Logan et al., 2008; Nath et al., 2017; Oman et al., 2011; Thompson et al., 2011; Guang Zeng \& Pyle, 2005; Ziemke et al., 2010; Ziemke \& Chandra, 2003). ENSO

85 induces both changes in atmospheric dynamics, i.e., STE and transport patterns, and changes in emissions, particularly biomass burning, that affect photochemical production of $\mathrm{O}_{3}$. Atmospheric circulation changes during El Niño and La Niña years result in strong changes in STE; anomalously large $\mathrm{STE} \mathrm{O}_{3}$ fluxes are found to follow an El Niño year (with about six months' time lag), while La Niña events result in a decrease of STE (Guang Zeng \& Pyle, 2005). During intense El Niño events, emission changes dominate $\mathrm{O}_{3}$ variability, whereas, in less intense El Niño events, dynamical changes dominate (Inness et al., 2015).

90 During the El Niño years, the large scale dipole area of low and high pressure over the tropical Pacific, which drives the Walker circulation weakens; the low-pressure convective area over the maritime continent moves towards the central Pacific, resulting in large scale changes over the whole Pacific ocean such as those intensifying wildfires over Indonesia. Because these large patterns of climate variability are systematically repeated over the years, Ziemke and Chandra (2003) suggested that the decadal variability of the tropospheric column of $\mathrm{O}_{3}$ in the tropics is driven by the combined effect of La Niña and El Niño.

95 More specifically, $\mathrm{O}_{3}$ is increasing over the west Pacific and decreasing over the central and Eastern Pacific after an El Niño (Logan et al., 2008; Oman et al., 2011; Guang Zeng \& Pyle, 2005; Ziemke \& Chandra, 2003). Zeng and Pyle (2005) simulated a mid-troposphere $\mathrm{O}_{3}$ increase by more than $10 \mathrm{ppb}_{\mathrm{v}}$ in the Western Pacific and a decrease in the Eastern Pacific after the 1997 El Niño, in agreement with observations; clearly showing differences in the response of the Western and the Eastern Pacific to environmental changes. Similarly, Oman et al. (2011) evaluated the sensitivity of $\mathrm{O}_{3}$ from the surface to the upper troposphere to ENSO anomalies over a period of 25 years. They found a positive response to positive anomalies in El Niño in 
the Western Pacific and the Indian Ocean at all altitudes and a negative response in the Eastern and Central Pacific. However, the interannual change in tropospheric $\mathrm{O}_{3}$ due to ENSO is smaller than the combined impact of intra-seasonal MJO and shorter timescale variability that drives the non-ENSO variability (Ziemke et al., 2015). In addition, the impacts of ENSO have changed over the last 20 years (Z.-Z. Hu et al., 2020); for instance, ENSO-3.4 warming of the tropical Pacific was a good predictor for precipitation over Central Chile but is not anymore (Garreaud et al., 2020).

Available surface observations and ozonesondes in the tropical Pacific show a significant increase in surface $\mathrm{O}_{3}$ at $\mathrm{Mauna}_{\mathrm{L}} \mathrm{aa}$ Observatory of $0.16 \mathrm{ppb}_{\mathrm{v}} \mathrm{y}^{-1}$ since 1974; while in American Samoa, the observed trend of $0.01 \mathrm{ppb}_{\mathrm{v}} \mathrm{y}^{-1}$ (from 1976 to 2010 ) is statistically insignificant (S. J. Oltmans et al., 2013). The increase observed in the early part of the $\mathrm{O}_{3}$ record (1981-2010) has leveled off in the most recent decade (1991-2010) (S. J. Oltmans et al., 2013). Gallardo et al. (2016) report a significant

110 trend of $0.15 \mathrm{ppb}_{\mathrm{v}} \mathrm{y}^{-1}$ (1994-2014) for near-surface ozone at Rapa Nui in the Eastern Pacific. Analysis of 6-years (1997-2003) of data from ozonesondes at four locations in the south Pacific has shown that, for the Western Pacific, the seasonal displacement of the South Pacific Convergence Zone (SPCZ) is affecting transport patterns. Both photochemistry and transport patterns control the variability and seasonality in surface $\mathrm{O}_{3}$ levels (Chandra et al., 2014). On the other hand, $\mathrm{O}_{3}$ observations at high altitude $(2.2 . \mathrm{km})$ station of El Tololo in Chile have shown a clear increasing trend from 1995 to 2010 that is strongly

115 related with stratospheric $\mathrm{O}_{3}$ influx to the troposphere, with maxima in spring that are shifted during recent years to earlier times than before (Anet et al., 2017). At the South Pole, the decreasing trend over the first part of the 1991-2010 period has been reversed in the last years, and $\mathrm{O}_{3}$ levels have recovered. The Northern Hemisphere mid-latitudes $\mathrm{O}_{3}$ changes are most likely attributed to the $\mathrm{O}_{3}$ precursor emission controls (S. J. Oltmans et al., 2013).

Because all tropospheric $\mathrm{O}_{3}$ precursors have significant anthropogenic and biomass burning emissions, the baseline levels of the tropospheric ozone have increased since the preindustrial era. Jaffe and Wigder (2012) used estimates of the CO emissions from wildfires and a molar $\Delta \mathrm{O}_{3} / \Delta \mathrm{CO}$ ratio of 0.4 for the tropics and 0.2 for the other regions to evaluate that the global tropospheric $\mathrm{O}_{3}$ production by wildfires is about $170 \mathrm{Tg} \mathrm{O}_{3} \mathrm{y}^{-1}$ (i.e., about 3.5\% of all global tropospheric $\mathrm{O}_{3}$ production). They also estimated that about $30 \%$ of this amount is produced south of $10^{\circ} \mathrm{S}$. Global simulations have also shown that wildfires increase the tropospheric loads of $\mathrm{O}_{3}$ by $3 \%, \mathrm{CO}$ by $13 \%$, particulate organic carbon by $30 \%$ and black carbon by $35 \%$ ( $\mathrm{N}$.

125 Daskalakis et al., 2015).

While $\mathrm{O}_{3}$ variability is impacted by changes in precursors' emissions and dynamical effects due to $\mathrm{O}_{3}$ 's relatively long residence time, CO concentrations are mainly driven by emissions (N. Daskalakis et al., 2015; Inness et al., 2015). The dispersion and transport patterns of biomass burning emissions vary upon the location of the sources (Samuel J. Oltmans et al., 2001; Thompson et al., 2003). Tropical emissions are affected by the Hadley circulation with strong upward convective

130 flow at the intertropical convergence zones (Tosca et al., 2013). This transport mechanism brings pollution to the mid and high troposphere, which is further advected northward or southward, affecting even remote marine locations in the tropical Pacific (Anderson et al., 2016). Distant biomass burning emissions emanating from Southern Africa, Southeast Asia and South America have been shown to be the main contributors to the tropospheric pollution of $\mathrm{CO}$ and $\mathrm{O}_{3}$ in the West Pacific. This conclusion has been based on tropospheric column measurements by Fourier transform infrared (FTIR) and daily ozonesondes 
135 during a ship cruise in a north-south transit in the west Pacific, and further analysis of these data with the help of global modeling of tagged $\mathrm{CO}$ and $\mathrm{O}_{3}$ from 6 continental regions (Ridder et al., 2012).

Despite the above-mentioned progress made in our understanding of tropospheric ozone abundances and precursors in the tropical South Pacific Ocean, no systematic long-term study exists in the literature that integrates the $\mathrm{O}_{3}$ variability over the entire tropical and subtropical south Pacific from west to east. This is important because the west tropical, the east tropical and

140 the subtropical pristine Pacific areas are affected by air masses originating from different distant sources and atmospheric dynamics.

Hence, the present study takes into consideration the entire south tropical and subtropical Pacific Ocean to a) understand the tropospheric $\mathrm{O}_{3}$ variability in this region, b) disentangle the origin of $\mathrm{O}_{3}$ precursors and $\mathrm{CO}$ sources, c) understand observed patterns based on atmospheric dynamics variability, d) attribute and quantify the $\mathrm{CO}$ enhancement by biomass burning to specific source regions, and e) quantify the biomass burning contribution to $\mathrm{O}_{3}$ levels and its importance for $\mathrm{O}_{3}$ compared to the stratospheric $\mathrm{O}_{3}$ influx. To pursue the above, ozone observations from ozonesondes and in situ ground-based observations for CO (Figure 1), alongside satellite observations for both trace gases and a global 3-dimensional chemistry-transport model (CTM), were used. The CTM was driven by year-specific assimilated meteorology (ECMWF ERA interim for the years 19802014) and accounted for tagged CO tracers from biomass burning from the 13 different regions defined by the Hemispheric

150 Transport of Air Pollution (HTAP) task force.

\section{Data and methods}

\subsection{Modelling}

\subsubsection{Model description}

The model used here is the well-documented, global 3-dimensional, off-line chemistry and transport model TM4-ECPL. The

155 version of the model used for the present study has been described in detail by Daskalakis et al. (2015, 2016). Thus, hereafter we provide only information that is directly relevant to the present study. The model is driven by the ECMWF ERA-Interim meteorology (Dee et al., 2011), updated every 3 hours, and runs in a horizontal resolution of $3^{\circ} \mathrm{x} 2^{\circ}$ (longitude $\mathrm{x}$ latitude), with 34 hybrid vertical layers up to $10 \mathrm{hPa}$ (approximately $65 \mathrm{~km}$ ).

Most of the model's vertical layers (between 20 and 25, depending on location) lie in the troposphere allowing for

160 comprehensive tropospheric calculations. In the stratosphere, the model uses an oversimplified chemical scheme. To account for proper upper boundary conditions, the $\mathrm{O}_{3}$ concentrations above $50 \mathrm{hPa}$ altitude are nudged to monthly mean observations from the Microwave Scanning Radiometer (MSR) satellite instrument for the years 1980-2008, and the Global Ozone Monitoring Experiment (GOME2) for the years 2009 onwards, interpolated to the model levels by the Royal Netherlands Meteorological Institute (KNMI) (Van Der A et al., 2010). Using the stratospheric ozone concentration, the model calculates 

$\left(\mathrm{CH}_{4}\right)$ concentration in the stratosphere is forced to the HALOE $\mathrm{CH}_{4}$ climatology (Huijnen et al., 2010).

The model accounts for emissions of gases and aerosols from anthropogenic and biomass burning sources from the Atmospheric Chemistry and Climate Intercomparison Project (ACCMIP) emission database (Lamarque et al., 2013) up to the year 2000, and from the Representative Concentrations Pathways RCP6.0 (Fujino et al., 2006; van Vuuren et al., 2011) from

1702001 onwards. In particular, biomass burning emissions vary monthly, and their injection height follows the AEROCOM recommendations (Dentener et al., 2006).

\subsubsection{Simulations}

To assess the atmospheric composition of the tropical and subtropical Pacific Ocean and its drivers, three simulations were performed. For the first one, the base case simulation, the model run continuously from 1980-2014, saving gridded monthly averaged concentrations of 120 trace gases and aerosol components, and hourly gridded 3D fields for selected pollutants $\left(\mathrm{O}_{3}\right.$, $\mathrm{NO}_{x}, \mathrm{CO}$ ). A spin-up time of 14 years is used to bring the model into dynamic equilibrium between sources and atmospheric concentrations for all species. Therefore, the model output analysis is limited to 21 years, from 1994 to 2014 . To assess the impact of large-scale wildfires, a second simulation with omitted biomass burning emissions was performed, that was identical to the base simulation in every other aspect.

180 A third simulation, identical to the base simulation but with the addition of tagged species for biomass burning CO, was used to determine the impact of open fires from different regions on $\mathrm{CO}$ levels in the study area. For this, we split the globe into 13 source regions based on the source regions of the Task Force on Hemispheric Transport of Air Pollution (TF HTAP, Galmarini et al., 2017; HTAP, 2010). The regions are Europe, North Africa, southern Africa, Russia, "The Stans", Saudi Arabia, India, China, Southeast Asia, Oceania, North America, and South America. For each of the regions, a tracer was added in the model

185 with the same regional biomass burning emissions and the same removal processes as CO through wet and dry deposition and oxidation by hydroxyl radical $(\mathrm{OH})$, but without impacting the concentrations of $\mathrm{OH}$ and other chemicals in the model.

\subsection{Observations}

For the validation of the model results, a set of observations was used to compare the simulated concentrations against. In situ measurements for $\mathrm{O}_{3}$ were obtained from the European Monitoring and Evaluation Programme (EMEP) network for Europe

190 and from the National Oceanic and Atmospheric Administration (NOAA) and the World Data Center for Greenhouse Gases (WDCGG) for the rest of the world. Ozonesonde data were obtained from the Southern Hemisphere ADditional OZonesondes (SHADOZ) database, extended with data for Rapa Nui (sec. 2.2.1). Carbon monoxide surface measurements were also obtained from NOAA and WDCGG (sec. 2.2.2). Since the model has been validated against the surface $\mathrm{O}_{3}$ and $\mathrm{CO}$ observations around the globe (Nikos Daskalakis et al., 2016), the focus here is on the south Pacific regions. 


\subsubsection{In situ data}

We use the SHADOZ database, which is extensively described in the literature (Stauffer et al., 2018; Thompson et al., 2017; Witte et al., 2017, 2018). The focus area is the tropical and subtropical Southern Pacific, and the measurement sites are shown in Figure 1. For the present study, 20 years of ozone soundings collected by the Chilean Weather Office at Rapa Nui (Gallardo et al., 2016) have also been taken into account. The location of the stations (also shown in Figure 1), together with the number of soundings considered in this study, are summarized in Table 1. For optimal comparison of the modeled data to ozonesonde measurements between 1994 and 2014, hourly model values were sampled for a 3-hour period covering each ozonesonde flight, while the measurements were averaged over height to fit the model's vertical resolution for the specific time and date of the ozonesonde flight.

Carbon monoxide (CO) has been measured in flasks collected weekly at several sites around the world over the last two decades by NOAA (Novelli, 2014; Petron et al., 2018). These data were recently revised and calibrated, providing a consistent database including weekly and monthly averaged values. Out of this collection, we focus on the analysis of data from Samoa and Rapa Nui in the western and eastern Pacific, respectively.

\subsubsection{Satellite data}

The model results are compared with the Tropospheric Ozone Column (TOC) derived from the Ozone Monitoring Instrument (OMI), and the Microwave Limb Sounder (MLS) ozone measurements described by Ziemke et al. (2011). Both OMI and MLS instruments are onboard the Aura satellite with an overpass at 13:30 local time and typical spatial resolutions of $13 \mathrm{~km} \times 25$ $\mathrm{km}$ and $5 \mathrm{~km} \quad \mathrm{x} 500 \mathrm{~km} \quad(\mathrm{x} \quad 3 \mathrm{~km}$ vertically), respectively. These data are available at https://acdext.gsfc.nasa.gov/Data_services/cloud_slice/new_data.html, since October 2004.

The Measurements of Pollution In The Troposphere (MOPITT) satellite instrument onboard the Terra satellite has been

215 providing data (with a typical spatial resolution of $22 \mathrm{~km} \mathrm{x} 22 \mathrm{~km}$ at 10:30 and 22:30 local time), including tropospheric CO columns, for nearly 20 years (Deeter et al., 2017). The data product used here is the V7 (Deeter et al., 2019). It contains monthly averaged CO columns for the period April 2000 until present. These data were obtained from the National Aeronautics and Space Administration (NASA) Langley Research Center Atmospheric Science Data Center (NASA-Langley, 2018).

\subsubsection{Assessing trends and variability modes}

220 We assessed the ENSO-driven variability by exploring the linear correlation of deseasonalized and detrended time series of $\mathrm{CO}$ and ozone with the bi-monthly Multivariate El Niño/Southern Oscillation (ENSO) Index (MEI.v2) (Wolter \& Timlin, 2011). This index considers the combined expression of ENSO on sea level pressure (SLP), sea surface temperature (SST), surface zonal winds (U), surface meridional winds (V), and Outgoing Longwave Radiation (OLR) for ENSO conditions from 1979 to present (https://www.psl.noaa.gov/enso/mei/). We chose this multivariate index to account for the multiple processes 225 affecting the whole Pacific Ocean rather than one single aspect during diverse ENSO events. Also, MEI filters out shorter 
period variability, such as MJO, which is precluded by the weekly sampling of CO and ozone observations. It is also worth noting that ENSO patterns and teleconnections (impacts) have been subject to changes over the last few decades, which makes the choice of more robust ENSO indices particularly difficult (Capotondi et al., 2014; Z.-Z. Hu et al., 2020).

To assess trends, we used the Lamsal et al. (2015) method. This method uses a regression model to split the signal into three components: the seasonal component (harmonic functions), the linear trend component, and the residual component. The method also accounts for an error that considers auto-correlation and length of the monthly time series, as reported by Tiao (1990). To avoid the variability due to the MJO, we consider a bimonthly running average of $\mathrm{O}_{3}$ and $\mathrm{CO}_{\text {mixing }}$ ratios when estimating trends.

\section{Results and discussion}

\subsection{Climatology for the period 1994-2014}

The overall performance of the TM4-ECPL model in its current configuration has been previously thoroughly evaluated (e.g., Daskalakis et al., 2015, 2016; Kanakidou et al., 2012; Quennehen et al., 2016). Here we show and assess the model performance over the study region, namely the remote South Pacific. To this end, we first describe relevant large-scale circulation patterns, i.e., those capable of transporting the biomass burning outflow to the remote Pacific. Secondly, we characterize how the model reproduces ozone profiles collected over this area of the world for the period 1994-2014. Model calculated tropospheric columns of ozone and carbon monoxide are then compared with satellite observations.

\subsubsection{Circulation patterns affecting the remote Pacific Ocean}

The near-surface atmospheric circulation in the tropical and subtropical South Pacific is dominated by the South Pacific Convergence Zone (SPCZ), which consists of a mainly zonal tropical convergence zone and a diagonal subtropical branch that extends from Indonesia down to the mid-latitudes of the Southeastern Pacific (Brown et al., 2020). For most of the south Pacific, the Inter Tropical Convergence Zone (ITCZ) is climatologically located in the Northern Hemisphere; therefore, near surface tropical circulation in the Southeastern Pacific is characterized by cross-equatorial northeasterly trade winds. The SPCZ is a reverse-oriented monsoon trough that marks the preferential path of energy export from the warm Pacific pool in the tropics to mid-latitudes. The SPCZ axis also marks the maxima of the $500 \mathrm{hPa}$ upward vertical motion and the minimum in outgoing longwave radiation (OLR) (Figure 2, a and b). The SPCZ is located at the maximum of low-level convergence and separates the wet warm pool region from the dry subtropical Southeastern Pacific, which features the largest values of OLR over the Pacific (Figure 2b). The SPCZ axis location varies intraseasonally following the Madden-Julian Oscillation (MJO), interannualy due to ENSO, as well as on interdecadal and longer-time scales (e.g., Lintner and Boos, 2019; Vincent, 1994; Vincent et al., 2011). The SPCZ shifts equatorward and becomes more zonal during strong ENSO events (e.g., Brown et al.,

255 2020). In addition, winds blow towards the SPCZ from the northeast in the east tropical Pacific and weakly from the west in the west tropical Pacific (Figure 2b). The upper-level circulation is rather weak in the tropical band and features upper-level 
divergence which establishes an anticyclone associated with the main tropical convection in the warm pool. South of about $15^{\circ} \mathrm{S}$, climatological upper-level circulation is mostly zonal with a strong maximum south of the warm pool region where the meridional temperature gradient is at a maximum (Figure 2a). On a shorter timescale, SPCZ variability is affected by midlatitude Rossby waves and by tropical waves, in particular by the Madden-Julian Oscillation (MJO). MJO phase and intensity have a significant effect on the tropical and extratropical South Pacific weather (through teleconnections) and are responsible for short-term (weekly) changes in weather patterns. Both ENSO and MJO weather patterns affect atmospheric circulation in the southern Pacific and thus the transport of pollution into the region.

\subsubsection{Climatology of vertical ozone profiles}

Figure 1 shows 20-year ozone-sounding climatologies from six sites in the Pacific derived from observations and model outputs. Overall, there is a good agreement between observed and simulated ozone profiles when accounting for the temporal variability, while small positive biases are found in the boundary layer (BL) and the upper troposphere (UT), above 8 km when comparing the average values over the entire 20-year period (up to $50 \%$ and $25 \%$, respectively). The lack of halogen chemistry in the current model version may explain the BL bias, in line with modeling studies that show the importance of halogens for $\mathrm{O}_{3}$ depletion in the marine boundary layer (Pechtl \& von Glasow, 2007; Sherwen et al., 2016). The UT bias may be attributed to the treatment of the upper boundary conditions for ozone. In general, the model reproduces the variability of the measurements well (expressed as the standard deviation normalized by the mean), except at Watukosek (Java), where the model variability is much smaller than the one observed (average of $9 \mathrm{ppb}_{\mathrm{v}}$ across all altitudes and times for the model against $16 \mathrm{ppb}$ for the measurements). We attribute this mismatch to the vicinity of large and variable sources in Southeast Asia and

275 Australia that result in ozone formation events, the variability of which cannot be captured by the climatological (monthly mean) emissions of ozone precursors used in the model. Another factor contributing to this bias could be the relatively coarse model resolution $\left(3^{\circ} \times 2^{\circ}\right)$ that limits the accuracy in the representation of the synoptically driven ozone intrusions. However, the use of reanalysis meteorological data by the model is minimizing this potential bias, and the model is a powerful tool to understand $\mathrm{O}_{3}$ climatology in the study region.

\subsubsection{Tropospheric columns of $\mathrm{O}_{3}$ and $\mathrm{CO}$}

To further evaluate the model's ability to simulate the long-term variability in tropospheric $\mathrm{O}_{3}$ and $\mathrm{CO}$ amounts, we compare the model results with the retrieved tropospheric columns from OMI for ozone for the period 2004 - 2014 and total column of CO from MOPITT for the period 2000 - 2014. To optimize this comparison, we sampled the model at the satellites' overpass times, i.e., at 13:30 local time for $\mathrm{O}_{3}$ and at 10:30 and 22:30 local times for CO. The OMI/MLS product for $\mathrm{O}_{3}$ is publicly available and provided as monthly mean gridded values on a $1^{\circ} \times 1.25^{\circ}$ lat/lon grid, while for the MOPITT CO product, daily overpasses are available on a $22 \mathrm{~km}$ x $22 \mathrm{~km}$ resolution (at most two per day).

For $\mathrm{O}_{3}$, the model is sampled at the time and location of the satellite overpass and then averaged over the month. For a proper comparison to the OMI product, the tropospheric data are extracted from the model results by calculating the tropopause height 
based on a lapse-rate threshold as described in Reichler et al. (2003). This way a proper validation of the model against $\mathrm{O}_{3}$ satellite observations (Figure 3) is achieved. Unfortunately, no information is available on the quality control applied to the $\mathrm{OMI} / \mathrm{MLS} \mathrm{O}_{3}$ product or for potential missing values. Therefore, the full model dataset at the satellite overpass times (13:30 local time) is extracted, sampled and used to calculate monthly means for comparison with the satellite observations. Figure 3 shows good agreement between the simulated tropospheric $\mathrm{O}_{3}$ columns and the satellite product which corresponds to a Pearson correlation of 0.66 and a slope of 1.09 for the $\mathrm{SH}$ and a Pearson correlation of 0.76 and slope of 1.46 for NH (Figure 4). The main discrepancies are found in highly polluted areas (Beijing region, northern India, eastern U.S.A.), where the model calculates higher tropospheric $\mathrm{O}_{3}$ columns by up to 20 DU. These can be attributed to the model's vertical resolution that might not always accurately resolve the tropopause level, but also to the fact that the model seems to generally slightly overestimate surface $\mathrm{O}_{3}$ (by about $17 \%$ globally, Daskalakis et al. (2016)). Nonetheless, the model seems to capture the climatology of the global tropospheric ozone column, simulating high ozone in the vicinity of polluted areas as well as in the pollution outflows (e.g., southern Africa) that are of interest for the present study.

For the comparison with the CO MOPITT data, after sampling the model at the time and place of the observation, the results are weighted by the averaging kernel used for the MOPITT CO retrievals. This method leads to a model-derived product directly comparable to the satellite product and is shown in Figure 5. Thus, the model is validated against daily $\mathrm{CO}$ data. $\mathrm{CO}$ data from MOPITT are compared against the modelled tropospheric CO column (Figure 3). The calculated tropospheric CO columns derived using the averaging kernel of the observed data on the simulated data correspond to what the satellite would have observed if the model was an accurate representation of the reality. The model results are collocated to the observations, applying a quality control filter on both the modelled and observed data so that the comparison is accurate (i.e., we disregard values where the model surface pressure has a difference of more than $5 \mathrm{hPa}$ compared to the retrieved data, and we disregard all the retrieved data that are flagged as anomalous, meaning that these data should either be ignored or used cautiously). The comparison gives a very good agreement between model and satellite observations on $2^{\circ} \times 3^{\circ}$ spatial resolution, with a Pearson correlation of 0.93 and a slope of 0.8 for the period between 2000 and 2014 (15 years of daily collocated data). Further investigation of the differences between the observed and simulated CO concentrations reveals that the model overestimates CO over large wildfire regions of the South Hemisphere (southern Africa, South America, Indonesia), where differences between satellite and model tropospheric columns can reach up to 30\%. Over the subtropical Pacific Ocean, these differences

315 are below 10\%. However, CO long-term variability is captured by the model, as shown by Daskalakis et al. (2016) for continental sites and as discussed further for the South Pacific region (Sect. 3.2.2).

\subsection{Variability and trends}

In the previous section, we analyzed the climatology (long-term averages) of ozone and carbon monoxide. Here, we address seasonal and interannual variability patterns and to what extent the simulations capture them. The main drivers of variability are the temporal variations of emissions and photochemistry, and atmospheric dynamics that affect long-range transport and 
downward flux from the stratosphere. In the case of ozonesondes, the comparison is made for daily data, whereas in the case of $\mathrm{CO}$, we use monthly averaged data.

\subsubsection{Ozone variability as shown by ozonesondes}

For this analysis, we choose one representative station on each side of the Pacific Ocean, where there is an abundance of measurements to assess the observed and simulated ozone variability in the region. Figure 6 shows the comparison between model and ozone soundings over the Eastern and Western Pacific, represented by stations Rapa Nui and Samoa, respectively. We show the time series at $1.3 \mathrm{~km}$ (Figure 6(e) and (f)), $6.5 \mathrm{~km}$ (Figure 6 (c) and (d)) and $13.1 \mathrm{~km}$ (Figure 6 (a) and (b)) altitude as representative of the boundary layer, mid-troposphere, and upper troposphere-lower stratosphere (UTLS) regions, respectively. The positive model bias near the surface and in the UTLS shown in Figure 1 is also evident here. However, the overall variability of the time series is well captured by the model, particularly in the mid and lower troposphere, with Pearson correlations between 0.69 and 0.91 (Table 2). Only over Rapa Nui, the upper boundary condition translates into a poorer model performance with a normalized mean bias of $67 \%$. Both stations show a marked seasonal cycle, with maxima (minima) in spring (fall) at all levels, as well as interannual variability (not shown).

Using the Lamsal et al. (2015) approach, we estimated trends for observed and simulated ozone soundings on a bimonthly

335 basis (See Table 3). Over Rapa Nui, one finds a clear positive trend ( $\left.0.5 \pm 0.1 \mathrm{ppb}_{\mathrm{v}} / \mathrm{decade}\right)$ in the boundary layer observations, which is consistent with previous results (Gallardo et al., 2016). The model, on the other hand, indicates either a clear negative trend (-0.8 $\left.\pm 0.1 \mathrm{ppb}_{\mathrm{v}} / \mathrm{decade}\right)$ when considering all data points or a negligible/insignificant trend when considering only months with concurrent observations. This finding suggests that local pollution -not represented in the model- may in fact be affecting near-surface ozone as proposed by Gallardo et al. (2016). But other factors cannot be ruled out. In the mid-troposphere, the observations indicate a marginally negative trend, where the model shows decreasing ozone values $\left(-0.8 \pm 0.1 \mathrm{ppb}_{\mathrm{v}} / \mathrm{decade}\right)$. A negative trend is expected in connection with the widening and weakening of the Hadley circulation in a warming climate (Y. Hu et al., 2018; Lu et al., 2019). However, the magnitude of the decline is obscured by the possibly overestimated role of STE in the upper troposphere in the model simulations. Furthermore, the intermittence of ozone soundings over the southeast Pacific in this period hampers a definite assessment.

345 Observations over Samoa show marginally declining trends in near-surface $\left(-0.3 \pm 0.1 \mathrm{ppb}_{\mathrm{v}} / \mathrm{decade}\right)$ and a declining nonsignificant trend in mid-tropospheric ozone $\left(-0.1 \pm 0.2 \mathrm{ppb}_{\mathrm{v}} / \mathrm{decade}\right)$. These changes are in line with the recent findings by Thompson et al. (2021) for the period 1998-2019. TM4-ECPL reproduces the sign of the trend in the mid-troposphere but overestimates the magnitude when considering all data points as well as for the data points with concurrent observations (See Table 3). In the upper troposphere, the observations show a strong increasing trend ( $\left.2.6 \pm 0.3 \mathrm{ppb}_{\mathrm{v}} / \mathrm{decade}\right)$, larger than the trend computed by Thompson et al. (2021). There, depending on the number of data points considered, the TM4-ECPL calculates either a marginally positive trend (all model data), or a negative trend (concurrent data only), the reason probably being the different number of ENSO occurrences covered by the two datasets. An explicit representation of stratospheric chemistry in 
the chemistry-transport model as well as longer observed and simulated time series of $\mathrm{O}_{3}$ would enable a more accurate estimate of the trends in UTLS $\mathrm{O}_{3}$ as well as of the influence of ENSO.

355 With respect to the ENSO driven variability as expressed by the correlation with MEIv2 index, observations of midatmospheric ozone over Rapa Nui show a positive correlation during La Niña years $(+0.36)$; however, the correlation is not statistically significant at a $90 \%$ confidence level. This positive correlation is nevertheless consistent with a strengthened South Pacific high and increased subsidence. There are very few data during El Niño years that obscure a clear behavior at $6 \mathrm{~km}$. The model, on the other hand, shows a negative but significant correlation (-0.30) during La Niña and a positive and significant but weak correlation during El Niño (0.22). The latter is expected as the South Pacific high, and thus subsidence weakens in El Niño years. The former may be due to too strong influence of photochemistry compared with that of dynamics in the model despite the model's positive bias in the UTLS.

Over Samoa, where $\mathrm{O}_{3}$ levels are dominated by photochemistry, the observations show a positive correlation (0.33) during El Niño years linked to increased precursor emissions from biomass burning, and a small negative correlation (-0.13) during La

365 Niña years in connection with lesser emissions of ozone precursors in the Southern Hemisphere. However, this is not statistically significant, stressing the need to consider long time series to assess ENSO variability robustly. The model evidences a weaker but still positive and significant correlation during El Niño (0.23) and a clear negative correlation during La Niña.

\subsubsection{CO variability as shown by flask measurements}

370 The comparison between CO in situ observations and model results (Figure 7) evidences a general overestimation of CO mixing ratios from the model in the South Pacific Ocean, and a general underestimation of CO observations in the Northern Pacific Ocean. The corresponding mean bias is $7.6 \mathrm{ppb}_{\mathrm{v}}(8 \%)$ and $-6.4 \mathrm{ppb}_{\mathrm{v}}(-11 \%)$ for the South Pacific and the Northern Pacific Ocean stations, respectively. Both observations and model results show lower mixing ratios in the SH than in the NH. These features are illustrated in a scatter plot in Figure 7, where model versus observations at 14 stations (See Figure 1) are summarized. Further error statistics are shown in Table 4. Except for the root mean square error, the model performance is better for stations in the Northern Hemisphere than in the Southern Hemisphere of the remote Pacific.

Figure 8 shows the monthly mean time series of CO at Samoa (Western South Pacific) and Rapa Nui (Eastern South Pacific). The model reproduces the seasonality and the interannual variability of the $\mathrm{CO}$ observations, albeit with a positive bias of 6 $\%$ for Samoa and $9 \%$ for Rapa Nui, particularly in the low values of the austral spring. Pearson correlation is better at Rapa Nui than in Samoa (0.85 and 0.64 respectively), whereas the root mean square errors are somewhat smaller for Samoa than for Rapa Nui (6.3 for Samoa and 7.5 for Rapa Nui). This might be linked to inaccuracies in the biomass burning emissions, as revealed from the comparison with satellite observations (see Sect. 3.1.3).

The variability of observed surface mixing ratios of $\mathrm{CO}$ over the Pacific is not strongly modulated by ENSO over the period 1994-2014 (See Table 4). An exception is Guam (13.4N,144.7E), which is closest to the outflow of biomass burning from 
Indonesia. In Guam, ENSO explains ca. 60 \% of the observations' and model's variability in the period 1994-2014. There, during El Niño years, positive CO anomalies are found due to increased emissions from fires in Indonesia. The opposite happens during La Niña years. All other stations show a weak correlation with ENSO in the observations. This behavior is coherent with the findings of previous studies, according to which CO variability is mainly driven by emission changes and with relatively localized impacts (Inness et al., 2015).

On the other hand, the simulated CO shows higher ENSO modulation than the observations. Except in the mid-Pacific stations $-15^{\circ} \mathrm{N}, 145^{\circ} \mathrm{W} ; 10^{\circ} \mathrm{N}, 149^{\circ} \mathrm{W} ; 5^{\circ} \mathrm{N}, 151^{\circ} \mathrm{W}$, the difference cannot be attributed to the different number of data points considered in the observations and the simulated values, potentially altering the number of ENSO months realizations. Since we are using reanalysis meteorology, we attribute this mismatch to an ENSO driven variability in emissions that is not fully captured by the model.

395 The observations show significant decreasing trends in surface CO for all stations over the period 1994-2014 (See Table 6), except for Samoa where the trend is marginally significant. The simulated CO also shows decreasing trends but with weaker rates, typically half of those observed. In the northwest Pacific, model trends are small and marginally significant. The overall decreasing trends are expected in light of the reduction of anthropogenic emissions of CO due to applied legislation for clean air as well as the associated changes in hydroxyl radical concentrations and CO production by methane oxidation (Nikos

400 Daskalakis et al., 2016; Gaubert et al., 2017).

According to the simulations, biomass burning is responsible for a median contribution of $7 \%$ of surface CO over Rapa Nui and Samoa. Interestingly, over both sites, the largest contribution (ca. $40 \%$ of total biomass burning CO) emanates from Southern Africa due to circulation patterns connecting the African outflow with the subtropical westerly flow over the Pacific. The second-largest contributing biomass burning source area is Southeast Asia, which is responsible for $33 \%$ of biomass

405 burning CO in Samoa and $21 \%$ in Rapa Nui. Transport from this source region to the South Pacific occurs in connection with the equator crossing flow and uplifting associated with the SPCZ. South American biomass burning affect both Rapa Nui (17 $\%$ ) and Samoa (12\%). Over Rapa Nui, the contribution occurs mainly in connection with the tropical high-altitude easterly flow after convective uplifting over tropical South America. Over Samoa, this contribution emerges from the Atlantic outflow of the South American continent, followed by its confluence with westerly flow in higher latitudes.

\subsubsection{Stratospheric intrusions, biomass burning impact and transport pathways}

Figure 9 shows the cross-section (longitude over height) at $14^{\circ} \mathrm{S}$ (Samoa, tropics, (a), (b) and (c)) and $27^{\circ} \mathrm{S}$ (Rapa Nui, subtropics, (d), (e) and (f)) for the 21 year mean $\mathrm{O}_{3}$ concentrations ((a) and (d)), stratospheric $\mathrm{O}_{3}$ contribution ((b) and (e)) and the biomass burning contribution to $\mathrm{O}_{3}((\mathrm{c})$ and (f)) for the burning period of the $\mathrm{SH}$ (September, October, November; SON). The stratospheric $\mathrm{O}_{3}$ is a tagged species in the model tracing the ozone that originates from the stratosphere. The biomass

415 burning contribution is derived as the difference between the base simulation and the simulation without biomass burning emissions (deltaO3). In Figure $9 \mathrm{a}\left(14^{\circ} \mathrm{S}\right)$ the chemical tropopause $\left(\mathrm{O}_{3}\right.$ about $100 \mathrm{ppb}_{\mathrm{v}}$ for the $\mathrm{SH}$, Prather et al. (2011)) is not evident, while in Figure 9d $\left(27^{\circ} \mathrm{S}\right)$, the tropopause is seen at around $13 \mathrm{~km}$. This difference in tropopause altitude between the 
two locations is expected since $14^{\circ} \mathrm{S}$ (Figure 9a) is in the tropics closer to the ITCZ, the region where the tropopause is the highest (i.e., around $16 \mathrm{~km}$ that is out of the scale of the figure). In addition, in Figure 9d, a difference in the tropopause height is observed between the western (around $150^{\circ}-170^{\circ} \mathrm{E}$ ) and eastern (around $250^{\circ}-280^{\circ} \mathrm{E}$ ) Pacific (about $2 \mathrm{~km}$ lower in the west). The tropopause height also impacts the quantities of ozone penetrating from the stratosphere to the troposphere (Figure 9b,e), which are almost double at $27^{\circ} \mathrm{S}$ compared to $14^{\circ} \mathrm{S}$. The $27^{\circ} \mathrm{S}$ is affected by the downward branch of the Hadley cell resulting in an enrichment of the mid-troposphere by about $15-20 \mathrm{ppb}_{\mathrm{v}}$ of stratospheric $\mathrm{O}_{3}$. On the contrary, in the tropical South Pacific, this enrichment of the mid-troposphere is about 7-10 $\mathrm{ppb}_{\mathrm{v}}$. During the high burning season (SON), the $\mathrm{O}_{3}$ produced by the chemical aging of biomass burning emissions is higher in the tropics than in the subtropics. However, focusing on the Pacific Ocean region (longitudes between 150 and 280), we can see that there is a higher contribution of biomass burning to $\mathrm{O}_{3}$ levels (about 3 ppbv more) in the subtropics (Figure 9f) than in the tropics (Figure 9c). This enhancement is most evident over the entire sub-tropical Southern Pacific except for the BL of the Eastern South Pacific. This is caused by the transport patterns of the region that are driven by the tropical Hadley cell circulation with an upward convective flow at the intertropical convergence zone and downward fluxes at the subtropics. Southern westerlies dominate air flow at these latitudes. Figure 10 is the same as Figure 9, but for the low-burning period of the Southern Pacific Region (March, April, May; MAM), showing the importance of STE for $\mathrm{O}_{3}$ concentrations, which is larger at Rapa Nui than in Samoa as for SON.

Overall, STE is more important than the biomass burning contribution to $\mathrm{O}_{3}$ levels in the free troposphere over the tropical and subtropical Pacific Ocean. However, during SON biomass burning is almost as important as STE in the subtropical boundary layer. During the low burning period, the influence of biomass burning is seen in the high troposphere due to atmospheric transport patterns, as further discussed.

The use of tagged CO tracers enables the identification of biomass burning source areas that contribute to the CO levels in the South Pacific during the intensive burning period (SON) in the region. Figure 11 depicts the simulated vertical profiles of CO at the Samoa and Rapa Nui islands from the surface to $15 \mathrm{~km}$ altitude. It also shows the contribution of the total biomass burning sources and the major individual biomass burning source regions to the CO levels at these remote regions in the Southern Pacific. From this analysis, it is evident that open fires from Southeast Asia are the major contributors to CO from biomass burning at around $12 \mathrm{~km}$ both over Samoa and over Rapa Nui. At lower altitudes, open fires from South America and Southern Africa are also directly influencing the local CO levels. Notably, South America and Southern Africa have a larger influence on CO at Rapa Nui than at Samoa. This influence maximizes in the lower troposphere (i.e., at about 3-4 km). Overall, the biomass burning sources contribute $13 \%$ to $27 \%$ to CO concentrations at Rapa Nui and $13 \%$ to $30 \%$ at Samoa, depending on height.

Figures 12-15 demonstrate the global impact of biomass burning sources. They depict the contribution of biomass burning from the main source regions affecting the Southern tropical Pacific Ocean free troposphere and UTLS region (5 km height$12 \mathrm{~km}$ ) for June, July, August (JJA) and September, October, November (SON), when the impact of the fires maximizes. They 450 also show that wildfires close to ITCZ have a dual outflow. South American fires are transported westward and affect the tropical eastern Pacific. Eastward, through transport over the Atlantic and then the southern Indian Ocean, they reach the 
western subtropical Pacific (Samoa) and, finally, the Eastern Pacific (Rapa Nui), thus affecting the entire southern hemispheric ocean. Similarly, the fires in Southern Africa present a dual (northwest and southeast) outflow, affecting i) the tropical eastern Pacific, after crossing the Atlantic Ocean and ii) the southern Pacific after traveling over the Indian ocean and the Pacific. Fires over Southeast Asia will affect both westward the Indian Ocean and eastward the southern Pacific. Lastly, the outflow of fires over Oceania also splits northwestward to the Indian Ocean and southeastward to the Pacific Ocean. The two different airflow corridors (northward and southward) from these regions are due to the location of the ITCZ and the SPCZ. Figure 12 demonstrates that biomass burning $\mathrm{CO}$ is reaching the south Pacific through mid-tropospheric transport.

$\mathrm{CO}$ from Africa is lifted by convection, getting into the westerlies flow that enables the $\mathrm{CO}$ transport from Africa to the remote Pacific. Similarly, CO from open fires in Southeast Asia (Indonesia) is lifted by convection in the warm pool and then splits into an eastward and a westward flow. The eastward convective outflow influences the entire southern Pacific Ocean, driven by the counter trade winds in the upper troposphere. As the flow moves to the east, it starts subsiding over the Eastern Pacific. $\mathrm{CO}$ from Oceania is lifted to lower altitudes than that from Southeast Asia, leaving the bulk of the emissions subject to transport by the winds in the lower troposphere (Figure 13). The fraction that is uplifted above $5 \mathrm{~km}$ is drawn into the Walker circulation, leading to trans-Pacific transport and affecting the mid-troposphere over the Eastern Pacific. CO from South American open fires in the lower troposphere is separated into two branches. One small part, blowing towards the Pacific by convective uplifting over the Andes and following easterly winds, and another drawn into the southward low-level jet, which brings biomass burning CO to the westerly, with a characteristic outflow over the South Atlantic (Freitas et al., 2005). The fraction uplifted over the tropical South Atlantic is also separated into two branches. The larger one is transported eastward by the counter trade winds (Figure 14).

\section{Conclusions}

By combining in situ and satellite observations of $\mathrm{O}_{3}$ and $\mathrm{CO}$ with a global 3-dimensional model of tropospheric chemistry for a 21 year period (1994 to 2014), we have been able to show the importance of stratospheric influx for $\mathrm{O}_{3}$ levels in the pristine marine environment of the tropical and subtropical south Pacific. This contribution of about $15-20 \mathrm{ppb}_{\mathrm{v}}$ of $\mathrm{O}_{3}$ in the midtroposphere is larger at Rapa Nui (close to the subtropical East Pacific) than in Samoa (tropical west Pacific).

We have also shown that biomass burning emissions by convective updraft over emission regions, followed by transport through the mid and high troposphere, subside over the East subtropical Pacific, affecting $\mathrm{O}_{3}$ and $\mathrm{CO}$ levels. Biomass burning contribution to $\mathrm{O}_{3}$ levels is estimated to maximize in the subtropical South Pacific (about $3 \mathrm{ppb}_{\mathrm{v}}$ ) over the entire free troposphere during the high burning period.

480 Over Rapa Nui, ca. $24 \%$ of CO in the free troposphere originates from biomass burning. Distant biomass burning areas contribute $80 \%$ of the total CO from biomass burning. These are Southeast Asia, mainly contributing to CO in the UTLS region and South America, South Africa and Oceania, affecting the entire tropospheric column. Over Samoa, we find a similar result, i.e., $26 \%$ of total $\mathrm{CO}$ and $80 \%$ of total biomass burning; however, the apportionment of sources is different. The 
dominant source throughout the tropospheric column is Southeast Asia, with its influence maximizing in the UTLS region (at about $13 \mathrm{ppb}_{\mathrm{v}}$ ). Therefore, biomass burning emissions affect even the most pristine region of the world, that is, the tropical and subtropical south Pacific.

\section{Acknowledgments}

ND, MK, and MV acknowledge support by the U Bremen Excellence Chair, MK acknowledges support by the Greek General

490 Secretariat of Research and Technology and the European Union Horizon 2020 project FORCeS under grant agreement No 821205. LG, RR and CM recognize the support from ANID FONDAP 15110009. The simulations and analysis of data were performed on the HPC cluster Aether at the University of Bremen, financed by DFG, within the scope of the Excellence Initiative.

\section{Authors' contribution}

Conceptualization, methodology, data interpretation and writing original draft ND, LG, MK; simulations ND, data processing ND, RN, CM, RR; visualization ND, LG, RN, CM, RR; funding acquisition, MK, LG and MV. All authors have contributed with scientific discussions to data interpretation, read and agreed to the published version of the manuscript.

\section{References}

Anderson, D. C., Nicely, J. M., Salawitch, R. J., Canty, T. P., Dickerson, R. R., Hanisco, T. F., Wolfe, G. M., Apel, E. C., Atlas, E., Bannan, T., Bauguitte, S., Blake, N. J., Bresch, J. F., Campos, T. L., Carpenter, L. J., Cohen, M. D., Evans, M., Fernandez, R. P., Kahn, B. H., ... Weinheimer, A. J. (2016). A pervasive role for biomass burning in tropical high ozone/low water structures. Nature Communications, 7(1), 10267. https://doi.org/10.1038/ncomms10267

Anet, G. J., Steinbacher, M., Gallardo, L., Velásquez Álvarez, A. P., Emmenegger, L., \& Buchmann, B. (2017). Surface ozone in the Southern Hemisphere: 20 years of data from a site with a unique setting in El Tololo, Chile. Atmospheric Chemistry and Physics, 17(10), 6477-6492. https://doi.org/10.5194/acp-17-6477-2017

Bowman, K. W., Shindell, D. T., Worden, H. M., Lamarque, J. F., Young, P. J., Stevenson, D. S., Qu, Z., De La Torre, M., Bergmann, D., Cameron-Smith, P. J., Collins, W. J., Doherty, R., Dalsøren, S. B., Faluvegi, G., Folberth, G., Horowitz, L. W., Josse, B. M., Lee, Y. H., MacKenzie, I. A., ... Worden, J. R. (2013). Evaluation of ACCMIP outgoing longwave radiation from tropospheric ozone using TES satellite observations. Atmospheric Chemistry and Physics, 13(8), 40574072. https://doi.org/10.5194/acp-13-4057-2013

Brown, J. R., Lengaigne, M., Lintner, B. R., Widlansky, M. J., van der Wiel, K., Dutheil, C., Linsley, B. K., Matthews, A. J., $\&$ Renwick, J. (2020). South Pacific Convergence Zone dynamics, variability and impacts in a changing climate. Nature Reviews Earth \& Environment, 1(10), 530-543. https://doi.org/10.1038/s43017-020-0078-2 
Capotondi, A., Wittenberg, A. T., Newman, M., Di Lorenzo, E., Yu, J.-Y., Braconnot, P., Cole, J., Dewitte, B., Giese, B., Guilyardi, E., Jin, F.-F., Karnauskas, K., Kirtman, B., Lee, T., Schneider, N., Xue, Y., \& Yeh, S.-W. (2014). Understanding ENSO Diversity. Bulletin of the American Meteorological Society, 96(6), 921-938. https://doi.org/10.1175/BAMS-D-13-00117.1

Chandra, A., Koshy, K., \& Maata, M. (2014). Surface ozone profiles at selected South Pacific sites. The South Pacific Journal of Natural and Applied Sciences, 32(2), 47. https://doi.org/10.1071/sp14008

Charlson, R. J. (2000). 7 - The Atmosphere. In M. C. Jacobson, R. J. Charlson, H. Rodhe, \& G. H. B. T.-I. G. Orians (Eds.), Earth System Science (Vol. 72, pp. 132-158). Academic Press. https://doi.org/https://doi.org/10.1016/S00746142(00)80113-8

Checa-Garcia, R., Hegglin, M. I., Kinnison, D., Plummer, D. A., \& Shine, K. P. (2018). Historical Tropospheric and Stratospheric Ozone Radiative Forcing Using the CMIP6 Database. Geophysical Research Letters, 45(7), 3264-3273. https://doi.org/10.1002/2017GL076770

Daskalakis, N., Myriokefalitakis, S., \& Kanakidou, M. (2015). Sensitivity of tropospheric loads and lifetimes of short lived pollutants to fire emissions. Atmospheric Chemistry and Physics, 15(6), 3543-3563. https://doi.org/10.5194/acp-153543-2015

Daskalakis, N., Tsigaridis, K., Myriokefalitakis, S., Fanourgakis, G. S., \& Kanakidou, M. (2016). Large gain in air quality compared to an alternative anthropogenic emissions scenario. Atmospheric Chemistry and Physics, 16(15), 9771-9784. https://doi.org/10.5194/acp-16-9771-2016

Dee, D. P., Uppala, S. M., Simmons, A. J., Berrisford, P., Poli, P., Kobayashi, S., Andrae, U., Balmaseda, M. A., Balsamo, G., Bauer, P., Bechtold, P., Beljaars, A. C. M., van de Berg, L., Bidlot, J., Bormann, N., Delsol, C., Dragani, R., Fuentes, M., Geer, A. J., ... Vitart, F. (2011). The ERA-Interim reanalysis: Configuration and performance of the data assimilation system. Quarterly Journal of the Royal Meteorological Society, 137(656), 553-597. https://doi.org/10.1002/qj.828

Deeter, M. N., Edwards, D. P., Francis, G. L., Gille, J. C., Mao, D., Martínez-Alonso, S., Worden, H. M., Ziskin, D., Andreae, M. O., \& Andreae, M. O. (2019). Radiance-based retrieval bias mitigation for the MOPITT instrument: The version 8 product. Atmospheric Measurement Techniques, 12(8), 4561-4580. https://doi.org/10.5194/amt-12-4561-2019

Deeter, M. N., Edwards, D. P., Francis, G. L., Gille, J. C., Martínez-Alonso, S., Worden, H. M., \& Sweeney, C. (2017). A climate-scale satellite record for carbon monoxide: The MOPITT Version 7 product. Atmospheric Measurement Techniques, 10(7), 2533-2555. https://doi.org/10.5194/amt-10-2533-2017

Dentener, F., Kinne, S., Bond, T., Boucher, O., Cofala, J., Generoso, S., Ginoux, P., Gong, S., Hoelzemann, J. J., Ito, A., Marelli, L., Penner, J. E., Putaud, J. P., Textor, C., Schulz, M., Van Der Werf, G. R., \& Wilson, J. (2006). Emissions of primary aerosol and precursor gases in the years 2000 and 1750 prescribed data-sets for AeroCom. Atmospheric Chemistry and Physics, 6(12), 4321-4344. https://doi.org/10.5194/acp-6-4321-2006

Ebojie, F., Burrows, J. P., Gebhardt, C., Ladstätter-Weißenmayer, A., Von Savigny, C., Rozanov, A., Weber, M., \& Bovensmann, H. (2016). Global tropospheric ozone variations from 2003 to 2011 as seen by SCIAMACHY. 
Atmospheric Chemistry and Physics, 16(2), 417-436. https://doi.org/10.5194/acp-16-417-2016

Fleming, Z. L., Doherty, R. M., Von Schneidemesser, E., Malley, C. S., Cooper, O. R., Pinto, J. P., Colette, A., Xu, X., Simpson, D., Schultz, M. G., Lefohn, A. S., Hamad, S., Moolla, R., Solberg, S., \& Feng, Z. (2018). Tropospheric Ozone Assessment Report: Present-day ozone distribution and trends relevant to human health. Elementa, 6(1), 12. https://doi.org/10.1525/elementa.273

Freitas, S. R., Longo, K. M., Silva Dias, M. A. F., Silva Dias, P. L., Chatfield, R., Prins, E., Artaxo, P., Grell, G. A., \& Recuero, F. S. (2005). Monitoring the transport of biomass burning emissions in South America. Environmental Fluid Mechanics, 5(1-2), 135-167. https://doi.org/10.1007/s10652-005-0243-7

Fujino, J., Nair, R., Kainuma, M., Masui, T., \& Matsuoka, Y. (2006). Multi-gas mitigation analysis on stabilization scenarios using aim global model. Energy Journal, 27(SPEC. ISS. NOV.), 343-353. https://doi.org/10.5547/ISSN0195-6574-EJVolSI2006-NoSI3-17

Gallardo, L., HenríQuez, A., Thompson, A. M., Rondanelli, R., Carrasco, J., Orfanoz-Cheuquelaf, A., \& Squez, P. V. (2016). The first twenty years (1994-2014) of ozone soundings from Rapa Nui $\left(27^{\circ} \mathrm{S}, 109^{\circ} \mathrm{W}, 51 \mathrm{~m}\right.$ a.s.1.). Tellus, Series B: Chemical and Physical Meteorology, 68(1), 29484. https://doi.org/10.3402/tellusb.v68.29484

Galmarini, S., Koffi, B., Solazzo, E., Keating, T., Hogrefe, C., Schulz, M., Benedictow, A., Jurgen Griesfeller, J., JanssensMaenhout, G., Carmichael, G., Fu, J., \& Dentener, F. (2017). Technical note: Coordination and harmonization of the multi-scale, multi-model activities HTAP2, AQMEII3, and MICS-Asia3: Simulations, emission inventories, boundary conditions, and model output formats. Atmospheric Chemistry and Physics, 17(2), 1543-1555. https://doi.org/10.5194/acp-17-1543-2017

Garreaud, R. D., Boisier, J. P., Rondanelli, R., Montecinos, A., Sepúlveda, H. H., \& Veloso-Aguila, D. (2020). The Central Chile Mega Drought (2010-2018): A climate dynamics perspective. International Journal of Climatology, 40(1), 421439. https://doi.org/10.1002/JOC.6219

Gaubert, B., Worden, H. M., Arellano, A. F. J., Emmons, L. K., Tilmes, S., Barré, J., Martinez Alonso, S., Vitt, F., Anderson, J. L., Alkemade, F., Houweling, S., \& Edwards, D. P. (2017). Chemical Feedback From Decreasing Carbon Monoxide Emissions. Geophysical Research Letters, 44(19), 9985-9995. https://doi.org/10.1002/2017GL074987

HTAP. (2010). Hemispheric Transport of Air Pollution 2010, PART A: OZONE AND PARTICULATE MATTER. In H. Dentener, F., Keating, T., and Akimoto (Ed.), AIR POLLUTION STUDIES (ECONOMIC C, Issue 17). UNITED NATIONS PUBLICATION. http://www.htap.org/publications/2010_report/2010_Final_Report/HTAP 2010 Part A 110407.pdf

Hu, Y., Huang, H., \& Zhou, C. (2018). Widening and weakening of the Hadley circulation under global warming. Science Bulletin, 63(10), 640-644. https://doi.org/10.1016/j.scib.2018.04.020

Hu, Z.-Z., Kumar, A., Huang, B., Zhu, J., L'Heureux, M., McPhaden, M. J., \& Yu, J.-Y. (2020). The Interdecadal Shift of ENSO Properties in 1999/2000: A Review. Journal of Climate, 33(11), 4441-4462. https://doi.org/10.1175/JCLI-D-190316.1 
Huang, L., Fu, R., \& Jiang, J. H. (2014). Impacts of fire emissions and transport pathways on the interannual variation of CO in the tropical upper troposphere. Atmospheric Chemistry and Physics, 14(8), 4087-4099. https://doi.org/10.5194/acp14-4087-2014

Huijnen, V., Williams, J., Van Weele, M., Van Noije, T., Krol, M., Dentener, F., Segers, A., Houweling, S., Peters, W., De Laat, J., Boersma, F., Bergamaschi, P., Van Velthoven, P., Le Sager, P., Eskes, H., Alkemade, F., Scheele, R., Nédélec, P., \& Pätz, H. W. (2010). The global chemistry transport model TM5: Description and evaluation of the tropospheric chemistry version 3.0. Geoscientific Model Development, 3(2), 445-473. https://doi.org/10.5194/gmd-3-445-2010

Inness, A., Benedetti, A., Flemming, J., Huijnen, V., Kaiser, J. W., Parrington, M., \& Remy, S. (2015). The ENSO signal in atmospheric composition fields: Emission-driven versus dynamically induced changes. Atmospheric Chemistry and Physics, 15(15), 9083-9097. https://doi.org/10.5194/acp-15-9083-2015

Jaffe, D. A., \& Wigder, N. L. (2012). Ozone production from wildfires: A critical review. Atmospheric Environment, 51, 110. https://doi.org/10.1016/j.atmosenv.2011.11.063

Jerrett, M., Burnett, R. T., Arden Pope, C., Ito, K., Thurston, G., Krewski, D., Shi, Y., Calle, E., \& Thun, M. (2009). Longterm ozone exposure and mortality. New England Journal of Medicine, 360(11), 1085-1095. https://doi.org/10.1056/NEJMoa0803894

Kanakidou, M., Myriokefalitakis, S., Daskalakis, N., Fanourgakis, G., Nenes, A., Baker, A. R., Tsigaridis, K., \& Mihalopoulos, N. (2016). Past, present, and future atmospheric nitrogen deposition. Journal of the Atmospheric Sciences, 73(5), 20392047. https://doi.org/10.1175/JAS-D-15-0278.1

Kanakidou, Maria, Duce, R. A., Prospero, J. M., Baker, A. R., Benitez-Nelson, C., Dentener, F. J., Hunter, K. A., Liss, P. S., Mahowald, N., Okin, G. S., Sarin, M., Tsigaridis, K., Uematsu, M., Zamora, L. M., \& Zhu, T. (2012). Atmospheric fluxes of organic $\mathrm{N}$ and $\mathrm{P}$ to the global ocean. Global Biogeochemical Cycles, 26(3). https://doi.org/10.1029/2011gb004277

Lacis, A. A., Wuebbles, D. J., \& Logan, J. A. (1990). Radiative forcing of climate by changes in the vertical distribution of ozone. Journal of Geophysical Research, 95(D7), 9971-9981. https://doi.org/10.1029/JD095iD07p09971

Lamarque, J. F., Shindell, D. T., Josse, B., Young, P. J., Cionni, I., Eyring, V., Bergmann, D., Cameron-Smith, P., Collins, W. J., Doherty, R., Dalsoren, S., Faluvegi, G., Folberth, G., Ghan, S. J., Horowitz, L. W., Lee, Y. H., MacKenzie, I. A., Nagashima, T., Naik, V., ... Zeng, G. (2013). The atmospheric chemistry and climate model intercomparison Project (ACCMIP): Overview and description of models, simulations and climate diagnostics. Geoscientific Model Development, 6(1), 179-206. https://doi.org/10.5194/gmd-6-179-2013

Lamsal, L. N., Duncan, B. N., Yoshida, Y., Krotkov, N. A., Pickering, K. E., Streets, D. G., \& Lu, Z. (2015). U.S. NO2 trends (2005-2013): EPA Air Quality System (AQS) data versus improved observations from the Ozone Monitoring Instrument (OMI). Atmospheric Environment, 110, 130-143. https://doi.org/10.1016/j.atmosenv.2015.03.055

Lintner, B. R., \& Boos, W. R. (2019). Using atmospheric energy transport to quantitatively constrain South Pacific convergence zone shifts during ENSO. Journal of Climate, 32(6), 1839-1855. https://doi.org/10.1175/JCLI-D-18- 
0151.1

Logan, J. A., Megretskaia, I., Nassar, R., Murray, L. T., Zhang, L., Bowman, K. W., Worden, H. M., \& Luo, M. (2008). Effects of the $2006 \mathrm{El}$ Niño on tropospheric composition as revealed by data from the Tropospheric Emission Spectrometer (TES). Geophysical Research Letters, 35(3), 1-5. https://doi.org/10.1029/2007GL031698

Lu, X., Zhang, L., Zhao, Y., Jacob, D. J., Hu, Y., Hu, L., Gao, M., Liu, X., Petropavlovskikh, I., McClure-Begley, A., \& Querel, R. (2019). Surface and tropospheric ozone trends in the Southern Hemisphere since 1990: possible linkages to poleward expansion of the Hadley circulation. Science Bulletin, 64(6), 400-409. https://doi.org/https://doi.org/10.1016/j.scib.2018.12.021

Meul, S., Langematz, U., Kröger, P., Oberländer-Hayn, S., \& Jöckel, P. (2018). Future changes in the stratosphere-totroposphere ozone mass flux and the contribution from climate change and ozone recovery. Atmospheric Chemistry and Physics, 18(10), 7721-7738. https://doi.org/10.5194/acp-18-7721-2018

Mills, G., Pleijel, H., Malley, C. S., Sinha, B., Cooper, O. R., Schultz, M. G., Neufeld, H. S., Simpson, D., Sharps, K., Feng, Z., Gerosa, G., Harmens, H., Kobayashi, K., Saxena, P., Paoletti, E., Sinha, V., \& Xu, X. (2018). Tropospheric ozone assessment report: Present-day tropospheric ozone distribution and trends relevant to vegetation. Elementa, 6(1), 47. https://doi.org/10.1525/elementa.302

Monks, P. S., Archibald, A. T., Colette, A., Cooper, O., Coyle, M., Derwent, R., Fowler, D., Granier, C., Law, K. S., Mills, G. E., Stevenson, D. S., Tarasova, O., Thouret, V., Von Schneidemesser, E., Sommariva, R., Wild, O., \& Williams, M. L. (2015). Tropospheric ozone and its precursors from the urban to the global scale from air quality to short-lived climate forcer. Atmospheric Chemistry and Physics, 15(15), 8889-8973. https://doi.org/10.5194/acp-15-8889-2015

Monks, P. S., Granier, C., Fuzzi, S., Stohl, A., Williams, M. L., Akimoto, H., Amann, M., Baklanov, A., Baltensperger, U., Bey, I., Blake, N., Blake, R. S., Carslaw, K., Cooper, O. R., Dentener, F., Fowler, D., Fragkou, E., Frost, G. J., Generoso, S., ... von Glasow, R. (2009). Atmospheric composition change - global and regional air quality. Atmospheric Environment, 43(33), 5268-5350. https://doi.org/10.1016/j.atmosenv.2009.08.021

Myhre, G., Shindell, D., Bréon, F.-M., Collins, W., Fuglestvedt, J., Huang, J., Koch, D., Lamarque, J.-F., Lee, D., Mendoza, B., Nakajima, T., Robock, A., Stephens, G., Takemura, T., \& Zhang, H. (2013). Anthropogenic and natural radiative forcing. In T. F. Stocker, D. Qin, G.-K. Plattner, M. Tignor, S. K. Allen, J. Boschung, A. Nauels, Y. Xia, V. Bex, \& P. M. Midgley (Eds.), Climate Change 2013 the Physical Science Basis: Working Group I Contribution to the Fifth Assessment Report of the Intergovernmental Panel on Climate Change (Vol. 9781107057, pp. 659-740). Cambridge University Press. https://doi.org/10.1017/CBO9781107415324.018

NASA-Langley. (2018). Level 3 MOPITT CO gridded monthly means (Near and Thermal Infrared Radiances) V008. Version 8 [Data set]. https://doi.org/10.5067/TERRA/MOPITT/MOP03JM_L3.008

Nath, D., Chen, W., Graf, H. F., Lan, X., \& Gong, H. (2017). Contrasting subtropical PV intrusion frequency and their impact on tropospheric Ozone distribution over Pacific Ocean in El-Niño and La-Niña conditions. Scientific Reports, 7(1), 11987. https://doi.org/10.1038/s41598-017-12278-7 
Nishimoto, E., \& Yoden, S. (2017). Influence of the stratospheric quasi-biennial oscillation on the Madden-Julian oscillation during austral summer. Journal of the Atmospheric Sciences, 74(4), 1105-1125. https://doi.org/10.1175/JAS-D-160205.1

Novelli, P. C. and K. A. M. (2014). Atmospheric Carbon Monoxide Dry Air Mole Fractions from the NOAA ESRL Carbon Cycle Cooperative Global Air Sampling Network, 1988-2013, Version: 2014-07-02. ftp://aftp.cmdl.noaa.gov/data/trace_gases/co/flask/surface/.

Oltmans, S. J., Lefohn, A. S., Shadwick, D., Harris, J. M., Scheel, H. E., Galbally, I., Tarasick, D. W., Johnson, B. J., Brunke, E. G., Claude, H., Zeng, G., Nichol, S., Schmidlin, F., Davies, J., Cuevas, E., Redondas, A., Naoe, H., Nakano, T., \& Kawasato, T. (2013). Recent tropospheric ozone changes - A pattern dominated by slow or no growth. Atmospheric Environment, 67, 331-351. https://doi.org/10.1016/j.atmosenv.2012.10.057

Oltmans, Samuel J., Johnson, B. J., Harris, J. M., Vömel, H., Thompson, A. M., Koshy, K., Simon, P., Bendura, R. J., Logan, J. A., Hasebe, F., Shiotani, M., Kirchhoff, V. W. J. H., Maata, M., Sami, G., Samad, A., Tabuadravu, J., Enriquez, H., Agama, M., Cornejo, J., \& Paredes, F. (2001). Ozone in the Pacific tropical troposphere from ozonesonde observations. Journal of Geophysical Research: Atmospheres, 106(D23), 32503-32525. https://doi.org/10.1029/2000JD900834

Oman, L. D., Ziemke, J. R., Douglass, A. R., Waugh, D. W., Lang, C., Rodriguez, J. M., \& Nielsen, J. E. (2011). The response of tropical tropospheric ozone to ENSO. Geophysical Research Letters, 38(13), n/a-n/a. https://doi.org/10.1029/2011GL047865

Pechtl, S., \& von Glasow, R. (2007). Reactive chlorine in the marine boundary layer in the outflow of polluted continental air: A model study. Geophysical Research Letters, 34(11). https://doi.org/10.1029/2007GL029761

Petron, G., Crotwell, A. M., Lang, P. M., \& Dlugokencky, E. (2018). Atmospheric Carbon Monoxide Dry Air Mole Fractions from the NOAA ESRL Carbon Cycle Cooperative Global Air Sampling Network, 1988-2017, Version: 2018-10-17. National Oceanographic and Admospheric Administration (NOAA), ftp://aftp.cmdl.noaa.gov/data/trace_gases/co/flask/surface/

Pöschl, U., \& Shiraiwa, M. (2015). Multiphase Chemistry at the Atmosphere-Biosphere Interface Influencing Climate and Public Health in the Anthropocene. Chemical Reviews, 115(10), 4440-4475. https://doi.org/10.1021/cr500487s

Prather, M. J., Zhu, X., Tang, Q., Hsu, J., \& Neu, J. L. (2011). An atmospheric chemist in search of the tropopause. Journal of Geophysical Research Atmospheres, 116(4). https://doi.org/10.1029/2010JD014939

Quennehen, B., Raut, J. C., Law, K. S., Daskalakis, N., Ancellet, G., Clerbaux, C., Kim, S. W., Lund, M. T., Myhre, G., Olivié, D. J. L., Safieddine, S., Skeie, R. B., Thomas, J. L., Tsyro, S., Bazureau, A., Bellouin, N., Hu, M., Kanakidou, M., Klimont, Z., ... Zhu, T. (2016). Multi-model evaluation of short-lived pollutant distributions over east Asia during summer 2008. Atmospheric Chemistry and Physics, 16(17), 10765-10792. https://doi.org/10.5194/acp-16-10765-2016

Reichler, T., Dameris, M., \& Sausen, R. (2003). Determining the tropopause height from gridded data. Geophysical Research Letters, 30(20). https://doi.org/10.1029/2003GL018240

685 Ridder, T., Gerbig, C., Notholt, J., Rex, M., Schrems, O., Warneke, T., \& Zhang, L. (2012). Ship-borne FTIR measurements 
of $\mathrm{CO}$ and $\mathrm{O} 3$ in the Western Pacific from $43 \mathrm{~N}$ to $35 \mathrm{~S}$ : An evaluation of the sources. Atmospheric Chemistry and Physics, 12(2), 815-828. https://doi.org/10.5194/acp-12-815-2012

Sherwen, T., Schmidt, J. A., Evans, M. J., Carpenter, L. J., Großmann, K., Eastham, S. D., Jacob, D. J., Dix, B., Koenig, T. K., Sinreich, R., Ortega, I., Volkamer, R., Saiz-Lopez, A., Prados-Roman, C., Mahajan, A. S., \& Ordóñez, C. (2016). Global impacts of tropospheric halogens $(\mathrm{Cl}, \mathrm{Br}, \mathrm{I})$ on oxidants and composition in GEOS-Chem. Atmospheric Chemistry and Physics, 16(18), 12239-12271. https://doi.org/10.5194/acp-16-12239-2016

Škerlak, B., Sprenger, M., \& Wernli, H. (2014). A global climatology of stratosphere-troposphere exchange using the ERAInterim data set from 1979 to 2011. Atmospheric Chemistry and Physics, 14(2), 913-937. https://doi.org/10.5194/acp14-913-2014

Stauffer, R. M., Thompson, A. M., \& Witte, J. C. (2018). Characterizing Global Ozonesonde Profile Variability From Surface to the UT/LS With a Clustering Technique and MERRA-2 Reanalysis. Journal of Geophysical Research: Atmospheres, 123(11), 6213-6229. https://doi.org/10.1029/2018JD028465

Stevenson, D. S., Young, P. J., Naik, V., Lamarque, J.-F. F., Shindell, D. T., Voulgarakis, A., Skeie, R. B., Dalsoren, S. B., Myhre, G., Berntsen, T. K., Folberth, G. A., Rumbold, S. T., Collins, W. J., MacKenzie, I. A., Doherty, R. M., Zeng, G., van Noije, T. P. C. C., Strunk, A., Bergmann, D., ... Archibald, A. (2013). Tropospheric ozone changes, radiative forcing and attribution to emissions in the Atmospheric Chemistry and Climate Model Intercomparison Project (ACCMIP). Atmospheric Chemistry and Physics, 13(6), 3063-3085. https://doi.org/10.5194/acp-13-3063-2013

Sudo, K., \& Akimoto, H. (2007). Global source attribution of tropospheric ozone: Long-range transport from various source regions. Journal of Geophysical Research Atmospheres, 112(12), D12302. https://doi.org/10.1029/2006JD007992

Sun, W., Hess, P., \& Tian, B. (2014). The response of the equatorial tropospheric ozone to the Madden-Julian Oscillation in TES satellite observations and CAM-chem model simulation. Atmospheric Chemistry and Physics, 14(21), 1177511790. https://doi.org/10.5194/acp-14-11775-2014

Thompson, A. M., Allen, A. L., Lee, S., Miller, S. K., \& Witte, J. C. (2011). Gravity and Rossby wave signatures in the tropical troposphere and lower stratosphere based on Southern Hemisphere Additional Ozonesondes (SHADOZ), $1998-2007$. Journal of Geophysical Research Atmospheres, 116(5). https://doi.org/10.1029/2009JD013429

Thompson, A. M., Stauffer, R. M., Wargan, K., Witte, J. C., Kollonige, D. E., \& Ziemke, J. R. (2021). Regional and Seasonal trends in tropical ozone from SHADOZ profiles: Reference for models and satellite products. Journal of Geophysical Research, 126. https://doi.org/10.1029/2021JD034691

Thompson, A. M., Witte, J. C., McPeters, R. D., Oltmans, S. J., Schmidlin, F. J., Logan, J. A., Fujiwara, M., Kirchhoff, V. W.

J. H., Posny, F., Coetzee, G. J. R., Hoegger, B., Kawakami, S., Ogawa, T., Johnson, B. J., Vömel, H., \& Labow, G. (2003). Southern Hemisphere Additional Ozonesondes (SHADOZ) 1998-2000 tropical ozone climatology 1. Comparison with Total Ozone Mapping Spectrometer (TOMS) and ground-based measurements. Journal of Geophysical Research: Atmospheres, 108(D2), 8238. https://doi.org/10.1029/2001JD000967

Thompson, A. M., Witte, J. C., Sterling, C., Jordan, A., Johnson, B. J., Oltmans, S. J., Fujiwara, M., Vömel, H., Allaart, M., 
Piters, A., Coetzee, G. J. R., Posny, F., Corrales, E., Diaz, J. A., Félix, C., Komala, N., Lai, N., Ahn Nguyen, H. T., Maata, M., ... Thiongo, K. (2017). First reprocessing of southern hemisphere additional ozonesondes (SHADOZ) ozone profiles (1998-2016): 2. comparisons with satellites and ground-based instruments. Journal of Geophysical Research: Atmospheres, 122(23), 13,000-13,025. https://doi.org/10.1002/2017JD027406

Tiao, G. C. (1990). Effects of autocorrelation and temporal sampling schemes on estimates of trend and spatial correlation. In Journal of Geophysical Research (Vol. 95, Issue D12). https://doi.org/10.1029/jd095id12p20507

Tosca, M. G., Randerson, J. T., \& Zender, C. S. (2013). Sciences ess Atmospheric Chemistry and Physics Climate of the Past Geoscientific Instrumentation Methods and Data Systems The Cryosphere Global impact of smoke aerosols from landscape fires on climate and the Hadley circulation. Atmos. Chem. Phys, 13, 5227-5241. https://doi.org/10.5194/acp$13-5227-2013$

Van Der A, R. J., Allaart, M. A. F., \& Eskes, H. J. (2010). Multi sensor reanalysis of total ozone. Atmospheric Chemistry and Physics, 10(22), 11277-11294. https://doi.org/10.5194/acp-10-11277-2010

van Vuuren, D. P., Edmonds, J., Kainuma, M., Riahi, K., Thomson, A., Hibbard, K., Hurtt, G. C., Kram, T., Krey, V., Lamarque, J.-F., Masui, T., Meinshausen, M., Nakicenovic, N., Smith, S. J., \& Rose, S. K. (2011). The representative concentration pathways: an overview. Climatic Change, 109(1), 5. https://doi.org/10.1007/s10584-011-0148-z

Vincent, D. G. (1994). The South Pacific convergence zone (SPCZ): a review. Monthly Weather Review, 122(9), 1949-1970. https://doi.org/10.1175/1520-0493(1994)122<1949:TSPCZA>2.0.CO;2

Vincent, E. M., Lengaigne, M., Menkes, C. E., Jourdain, N. C., Marchesiello, P., \& Madec, G. (2011). Interannual variability of the South Pacific Convergence Zone and implications for tropical cyclone genesis. Climate Dynamics, 36(9-10), 1881-1896. https://doi.org/10.1007/s00382-009-0716-3

Witte, J. C., Thompson, A. M., Smit, H. G. J., Fujiwara, M., Posny, F., Coetzee, G. J. R., Northam, E. T., Johnson, B. J., Sterling, C. W., Mohamad, M., Ogino, S. Y., Jordan, A., \& da Silva, F. R. (2017). First reprocessing of Southern Hemisphere ADditional OZonesondes (SHADOZ) profile records (1998-2015): 1. Methodology and evaluation. Journal of Geophysical Research, 122(12), 6611-6636. https://doi.org/10.1002/2016JD026403

Witte, J. C., Thompson, A. M., Smit, H. G. J., Vömel, H., Posny, F., \& Stübi, R. (2018). First Reprocessing of Southern Hemisphere ADditional OZonesondes Profile Records: 3. Uncertainty in Ozone Profile and Total Column. Journal of Geophysical Research: Atmospheres, 123(6), 3243-3268. https://doi.org/10.1002/2017JD027791

Wolter, K., \& Timlin, M. S. (2011). El Niño/Southern Oscillation behaviour since 1871 as diagnosed in an extended multivariate ENSO index (MEI.ext). International Journal of Climatology, 31(7), 1074-1087. https://doi.org/10.1002/joc.2336

750 Young, P. J., Naik, V., Fiore, A. M., Gaudel, A., Guo, J., Lin, M. Y., Neu, J. L., Parrish, D. D., Rieder, H. E., Schnell, J. L., Tilmes, S., Wild, O., Zhang, L., Ziemke, J., Brandt, J., Delcloo, A., Doherty, R. M., Geels, C., Hegglin, M. I., ... Zeng, G. (2018). Tropospheric ozone assessment report: Assessment of global-scale model performance for global and regional ozone distributions, variability, and trends. Elementa, 6(1), 10. https://doi.org/10.1525/elementa.265 
Zeng, G, Morgenstern, O., Braesicke, P., \& Pyle, J. A. (2010). Impact of stratospheric ozone recovery on tropospheric ozone and its budget. Geophysical Research Letters, 37(L09805), 1-5. https://doi.org/10.1029/2010GL042812

Zeng, Guang, \& Pyle, J. A. (2005). Influence of El Niño Southern Oscillation on stratosphere/ troposphere exchange and the global tropospheric ozone budget. Geophysical Research Letters, 32(1), 1-4. https://doi.org/10.1029/2004GL021353

Ziemke, J. R., \& Chandra, S. (2003). La Nina and El Nino - Induced variabilities of ozone in the tropical lower atmosphere during 1970-2001. Geophysical Research Letters, 30(3), 42-1-4. https://doi.org/10.1029/2002GL016387

760 Ziemke, J. R., Chandra, S., Labow, G. J., Bhartia, P. K., Froidevaux, L., \& Witte, J. C. (2011). A global climatology of tropospheric and stratospheric ozone derived from Aura OMI and MLS measurements. Atmospheric Chemistry and Physics, 11(17), 9237-9251. https://doi.org/10.5194/acp-11-9237-2011

Ziemke, J. R., Chandra, S., Oman, L. D., \& Bhartia, P. K. (2010). A new ENSO index derived from satellite measurements of column ozone. Atmospheric Chemistry and Physics, 10(8), 3711-3721. https://doi.org/10.5194/acp-10-3711-2010

765 Ziemke, J. R., Douglass, A. R., Oman, L. D., Strahan, S. E., \& Duncan, B. N. (2015). Tropospheric ozone variability in the tropics from ENSO to MJO and shorter timescales. Atmospheric Chemistry and Physics, 15(14), 8037-8049. https://doi.org/10.5194/acp-15-8037-2015 
Table 1. Ozone sounding stations in the Pacific Ocean considered in this study. Data were obtained from Southern Hemisphere ADditional OZonesondes (SHADOZ, https://tropo.gsfc.gov/shadoz/) and from Rapa Nui from http://www.cr2.cl/datos-ozonsonda/.

\begin{tabular}{|l|l|l|l|l|l|}
\hline \multirow{2}{*}{ Name } & \multicolumn{2}{|l|}{ Location } & $\begin{array}{l}\text { Period } \\
\text { Covered by } \\
\text { observations } \\
\text { considered }\end{array}$ & $\begin{array}{l}\text { Number of } \\
\text { soundings } \\
\text { included in this } \\
\text { study for the } \\
\text { period 1994-2014 }\end{array}$ \\
\hline Watitude $\left(^{\circ}\right)$ & Longitude $\left.{ }^{\circ}\right)$ & $\begin{array}{l}\text { Altitude } \\
(\mathrm{m} \text { a.s.1. })\end{array}$ & & & 311 \\
\hline Samoa & $7.57 \mathrm{~S}$ & $112.65 \mathrm{E}$ & 50 & $1998-2013$ & 594 \\
\hline Suva & $14.25 \mathrm{~S}$ & $170.56 \mathrm{~W}$ & 42 & $1998-2018$ & 355 \\
\hline Rapa Nui & $18.15 \mathrm{~S}$ & $178.45 \mathrm{E}$ & 10 & $1998-2018$ & 234 \\
\hline San Cristóbal & $0.90 \mathrm{~S}$ & $89.6 \mathrm{~W}$ & 8 & $1998-2016$ & 428 \\
\hline Papeete & $18.0 \mathrm{~S}$ & $149.0 \mathrm{~W}$ & 2 & $1998-1999$ & 76 \\
\hline
\end{tabular}


https://doi.org/10.5194/acp-2021-640

Preprint. Discussion started: 31 August 2021

(c) Author(s) 2021. CC BY 4.0 License.

775 Table 2. Error statistics for model simulation versus observations of monthly averaged O3 for Rapa Nui and Samoa in the remote Pacific at three altitude levels. We show Pearson correlation (R), root mean square (RMS in ppbv), normalized mean bias (NMB in $\%$ ), and index of agreements (IA). The number of data points considered is also indicated. Calculations were made according to Brasseur and Jacob (2017).

\begin{tabular}{|c|c|c|c|c|c|c|}
\hline Location & $\begin{array}{c}\text { Altitude } \\
(\mathbf{k m})\end{array}$ & $\mathbf{R}$ & $\begin{array}{l}\text { RMS } \\
(\mathbf{p p b v})\end{array}$ & $\begin{array}{c}\text { NMB } \\
(\mathbf{\%})\end{array}$ & IA & $\begin{array}{c}\text { Data } \\
\text { Points }\end{array}$ \\
\hline \multirow{2}{*}{ Rapa Nui } & 13.1 & 0.42 & 81.6 & 67 & 0.44 & 109 \\
\cline { 2 - 7 } & 6.0 & 0.71 & 5.7 & -4 & 0.82 & 109 \\
\cline { 2 - 7 } & 1.3 & 0.81 & 6.7 & 19 & 0.66 & 109 \\
\hline \multirow{2}{*}{ Samoa } & 13.1 & 0.55 & 17.9 & 36 & 0.50 & 179 \\
\cline { 2 - 7 } & 6.0 & 0.69 & 7.3 & -14 & 0.70 & 179 \\
\cline { 2 - 7 } & 1.3 & 0.91 & 5.5 & 26 & 0.76 & 179 \\
\hline
\end{tabular}


Table 3. Estimated decadal ozone trends (ppbv per decade) at different altitudes over Rapa Nui and Samoa in the Pacific Ocean, according to observations and simulations for the period 1994-2014. Trends based on model values are calculated using all data points (Model) and only those concurrent with observations (Model*). Trends are calculated following Lamsal et al. (2015) and errors as in Tiao (1990). The number of data points $(N)$ considered is also indicated. Trends and errors are in ppbv/decade.

\begin{tabular}{|l|c|c|c|c|c|c|c|c|c|}
\hline \multirow{2}{*}{ Location } & \multicolumn{3}{|c|}{ Observations } & \multicolumn{3}{c|}{ Model } & \multicolumn{3}{c|}{ Model* } \\
\cline { 2 - 11 } & Trend & Error & N & Trend & Error & N & Trend & Error & N \\
\hline Rapa Nui (27.16S,109.4W) & & & & & & & & & \\
\hline $13.1 \mathrm{~km}$ & -1.6 & 0.3 & 109 & -10.1 & 0.9 & 251 & -1.4 & 0.6 & 109 \\
\hline $6 \mathrm{~km}$ & -0.2 & 0.1 & 109 & -0.8 & 0.1 & 251 & -1.0 & 0.1 & 109 \\
\hline $1.3 \mathrm{~km}$ & 0.5 & 0.1 & 109 & -0.8 & 0.1 & 251 & -0.1 & 0.1 & 109 \\
\hline Samoa (14.25S, 170.6W) & & & & & & & & & \\
\hline $13.1 \mathrm{~km}$ & 2.6 & 0.3 & 179 & 0.6 & 0.5 & 251 & -1.7 & 0.3 & 179 \\
\hline $6 \mathrm{~km}$ & -0.1 & 0.2 & 179 & -0.5 & 0.2 & 251 & -0.8 & 0.1 & 179 \\
\hline $1.3 \mathrm{~km}$ & -0.3 & 0.1 & 179 & 0.2 & 0.1 & 251 & -0.3 & 0.1 & 179 \\
\hline
\end{tabular}


Table 4. Error statistics for model simulation versus observations of CO for 14 stations in the remote Pacific. Symbols are as in Table 2.

\begin{tabular}{|l|c|c|c|c|c|}
\hline Location & R & $\begin{array}{l}\text { RMS } \\
\text { (ppbv) }\end{array}$ & $\begin{array}{c}\text { NMB } \\
(\mathbf{\%})\end{array}$ & IA & $\begin{array}{c}\text { Data } \\
\text { Points }\end{array}$ \\
\hline Christmas Island (1.70N, 157.1W) & 0.42 & 8.0 & 1 & 0.59 & 177 \\
\hline Guam (13.39N, 144.65E) & 0.85 & 12.9 & -10 & 0.86 & 239 \\
\hline Rapa Nui (27.16S,109.4W) & 0.85 & 7.5 & 9 & 0.78 & 222 \\
\hline Samoa (14.25S, 170.6W) & 0.64 & 6.3 & 6 & 0.72 & 252 \\
\hline Pacif. Ocean (15N,145W) & 0.86 & 16.0 & -14 & 0.8 & 190 \\
\hline Pacif. Ocean (10N,149W) & 0.86 & 13.1 & -11 & 0.8 & 194 \\
\hline Pacif. Ocean (5N,151W) & 0.59 & 10.1 & 0 & 0.66 & 195 \\
\hline Pacif. Ocean (0N/S,155W) & 0.36 & 9.1 & 6 & 0.59 & 191 \\
\hline Pacif. Ocean (5S,159W) & 0.45 & 6.9 & 5 & 0.63 & 186 \\
\hline Pacif. Ocean (10S,161W) & 0.59 & 6.0 & 6 & 0.66 & 189 \\
\hline Pacif. Ocean (15S,164W) & 0.72 & 7.4 & 9 & 0.69 & 195 \\
\hline Pacif. Ocean (20S,167W) & 0.86 & 10.6 & 15 & 0.68 & 184 \\
\hline Pacif. Ocean (25S,171W) & 0.86 & 13.5 & 20 & 0.59 & 193 \\
\hline Pacif. Ocean (30S,176W) & 0.85 & 15.3 & 23 & 0.52 & 193 \\
\hline Northern Hemisphere Stations & $\mathbf{0 . 8 3}$ & $\mathbf{1 2 . 4}$ & $\mathbf{- 8}$ & $\mathbf{0 . 8 4}$ & $\mathbf{9 9 5}$ \\
\hline Southern Hemisphere Stations & $\mathbf{0 . 6 3}$ & $\mathbf{9 . 6}$ & $\mathbf{1 1}$ & $\mathbf{0 . 6 5}$ & $\mathbf{1 8 0 5}$ \\
\hline
\end{tabular}


790 Table 5. Pearson correlation (R) and number data points (N) for bimonthly averaged CO values vs. MEIV.2 index according to observations and model. Model* indicates the same calculation but using only those data points for which there are concurrent observations.

\begin{tabular}{|l|c|c|c|c|c|c|}
\hline \multirow{2}{*}{ Location } & \multicolumn{2}{|c|}{ Observations } & \multicolumn{2}{c|}{ Model } & \multicolumn{2}{c|}{ Model * } \\
\cline { 2 - 6 } & $\mathbf{R}$ & $\mathbf{N}$ & $\mathbf{R}$ & $\mathbf{N}$ & $\mathbf{R}$ & $\mathbf{N}$ \\
\hline Christmas Island (1.70N, 157.1W) & -0.19 & 172 & -0.18 & 251 & -0.15 & 172 \\
\hline Guam (13.39N, 144.65E) & 0.60 & 234 & 0.58 & 251 & 0.58 & 234 \\
\hline Rapa Nui (27.16S,109.4W) & -0.04 & 217 & 0.23 & 251 & 0.24 & 217 \\
\hline Samoa (14.25S, 170.6W) & 0.10 & 251 & 0.24 & 251 & 0.24 & 251 \\
\hline Pacif. Ocean (15N,145W) & 0.16 & 185 & 0.37 & 251 & 0.30 & 185 \\
\hline Pacif. Ocean (10N,149W) & 0.05 & 190 & 0.35 & 251 & 0.22 & 190 \\
\hline Pacif. Ocean (5N,151W) & 0.04 & 191 & 0.01 & 251 & -0.24 & 191 \\
\hline Pacif. Ocean (0N/S,155W) & 0.07 & 186 & -0.18 & 251 & -0.33 & 186 \\
\hline Pacif. Ocean (5S,159W) & 0.16 & 182 & -0.25 & 251 & -0.26 & 182 \\
\hline Pacif. Ocean (10S,161W) & 0.09 & 185 & 0.16 & 251 & -0.14 & 185 \\
\hline Pacif. Ocean (15S,164W) & 0.27 & 191 & 0.20 & 251 & 0.23 & 191 \\
\hline Pacif. Ocean (20S,167W) & 0.17 & 179 & 0.36 & 251 & 0.39 & 179 \\
\hline Pacif. Ocean (25S,171W) & -0.10 & 184 & 0.33 & 251 & 0.31 & 184 \\
\hline Pacif. Ocean (30S,176W) & -0.01 & 189 & 0.32 & 251 & 0.32 & 189 \\
\hline
\end{tabular}


Table 6. Estimated trends of surface CO in the Pacific Ocean according to observations and model outputs for the period $1994-2014$. Trends are calculated following Lamsal et al. (2015) and errors as in Tiao. (1990). The number of data points (N) considered is also indicated. Trends and errors are in ppbv/decade.

\begin{tabular}{|l|c|c|c|c|c|c|}
\hline \multirow{2}{*}{ Location } & \multicolumn{3}{|c|}{ Observations } & \multicolumn{3}{c|}{ Model } \\
\cline { 2 - 7 } & Trend & Error & N & Trend & Error & N \\
\hline Christmas Island (1.70N, 157.1W) & -4.6 & 0.3 & 198 & -2.5 & 0.2 & 251 \\
\hline Guam (13.39N, 144.65E) & -5.2 & 0.5 & 196 & 0.3 & 0.4 & 251 \\
\hline Samoa (14.25S, 170.6W) & -0.5 & 0.2 & 200 & -1.7 & 0.1 & 251 \\
\hline Rapa Nui (27.16S,109.4W) & -3.7 & 0.2 & 209 & -2.0 & 0.1 & 251 \\
\hline Pacif. Ocean (30S,176W) & -2.7 & 0.3 & 238 & -1.8 & 0.2 & 251 \\
\hline Pacif. Ocean $(25 \mathrm{~S}, 171 \mathrm{~W})$ & -2.8 & 0.3 & 199 & -2.0 & 0.2 & 251 \\
\hline Pacif. Ocean $(20 \mathrm{~S}, 167 \mathrm{~W})$ & -3.9 & 0.3 & 201 & -2.0 & 0.1 & 251 \\
\hline Pacif. Ocean $(15 \mathrm{~S}, 164 \mathrm{~W})$ & -3.4 & 0.3 & 176 & -1.6 & 0.1 & 251 \\
\hline Pacif. Ocean $(10 \mathrm{~S}, 161 \mathrm{~W})$ & -2.4 & 0.2 & 197 & -1.7 & 0.1 & 251 \\
\hline Pacif. Ocean $(5 \mathrm{~S}, 159 \mathrm{~W})$ & -4.3 & 0.3 & 187 & -2.5 & 0.2 & 251 \\
\hline Pacif. Ocean $(0 \mathrm{~N} / \mathrm{S}, 155 \mathrm{~W})$ & -3.9 & 0.5 & 195 & -2.6 & 0.2 & 251 \\
\hline Pacif. Ocean $(5 \mathrm{~N}, 151 \mathrm{~W})$ & -3.9 & 0.5 & 251 & -1.8 & 0.2 & 251 \\
\hline Pacif. Ocean $(10 \mathrm{~N}, 149 \mathrm{~W})$ & -3.9 & 0.5 & 201 & -0.6 & 0.2 & 251 \\
\hline Pacif. Ocean $(15 \mathrm{~N}, 145 \mathrm{~W})$ & -6.1 & 0.7 & 190 & -0.5 & 0.2 & 251 \\
\hline
\end{tabular}



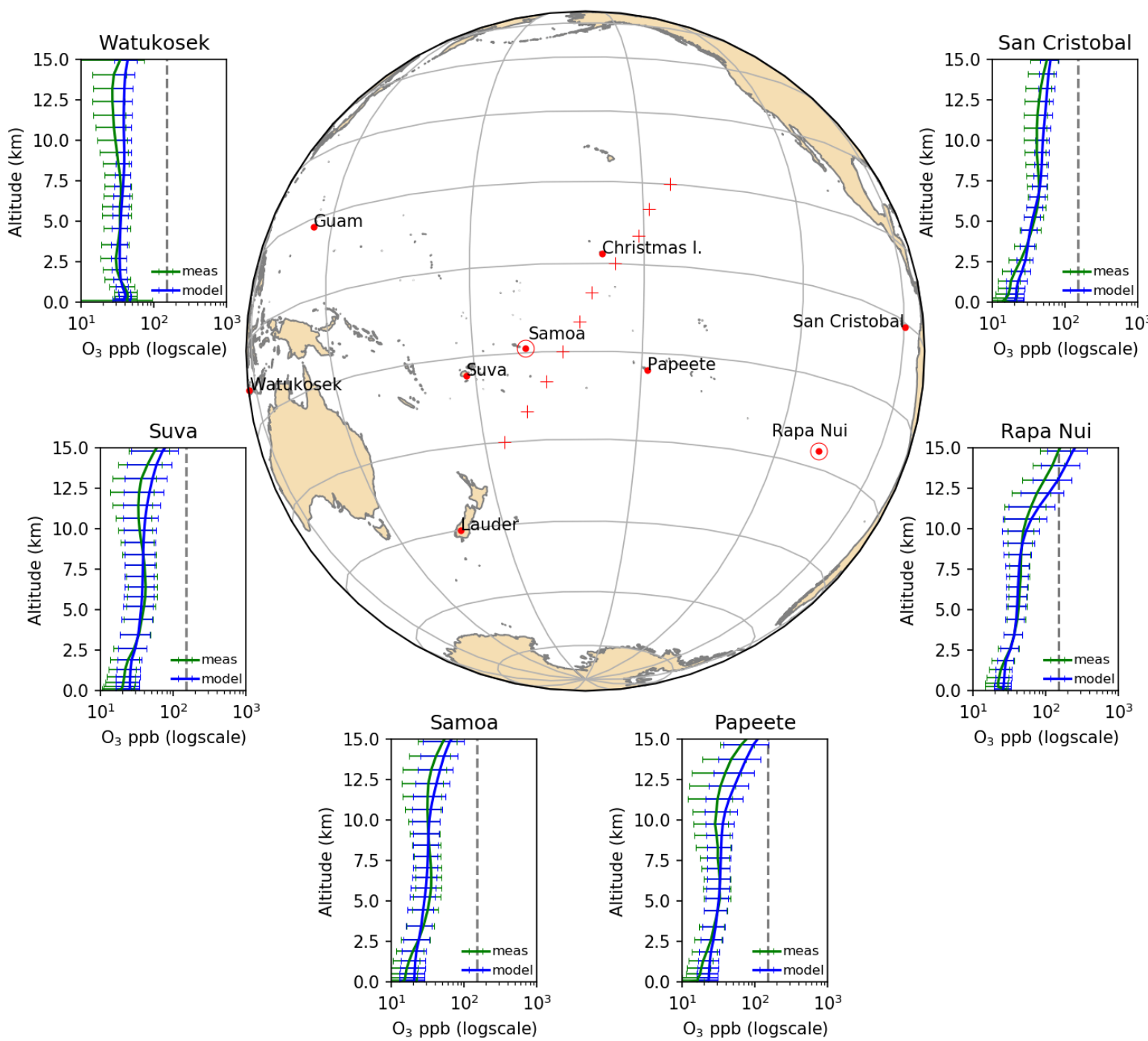

Figure 1. Area of study and ozone profile climatologies (1994-2014) as derived from the observations and simulations for six sites in the remote Pacific (red dots). The location of the stations is shown on the map. Also shown are the stations where surface CO measurements were considered (red + symbol). Ozone measurements are shown in green, and simulations in blue. The error bars correspond to one standard deviation of the mean. Rapa Nui and Samoa stations, where both O3 and CO observations are available, are marked with a dot and circle. Ozone data were obtained from https://tropo.gsfc.nasa.gov/shadoz/, except for Rapa Nui that was accessed at http://www.cr2.cl/datos-ozonosonda/. CO data come from https://www.esrl.noaa.gov/gmd/dv/data/ 
a)

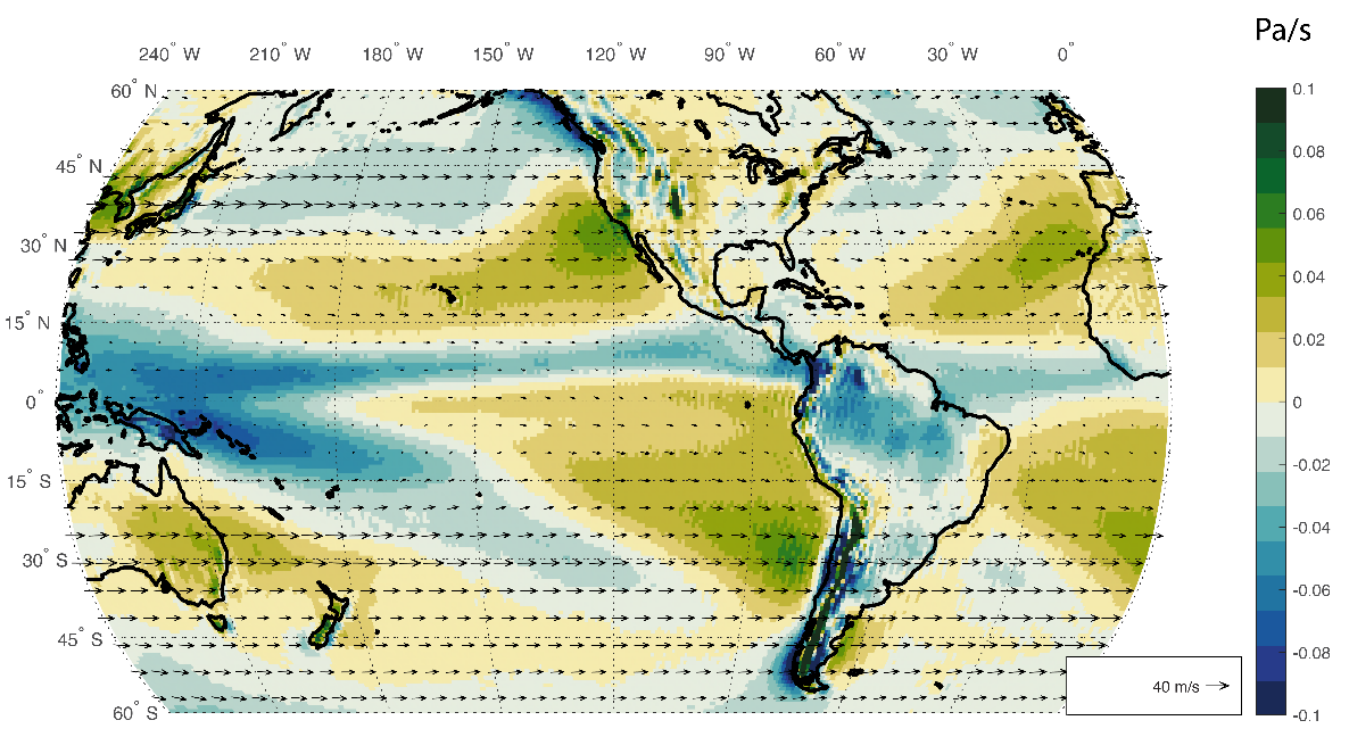

b)

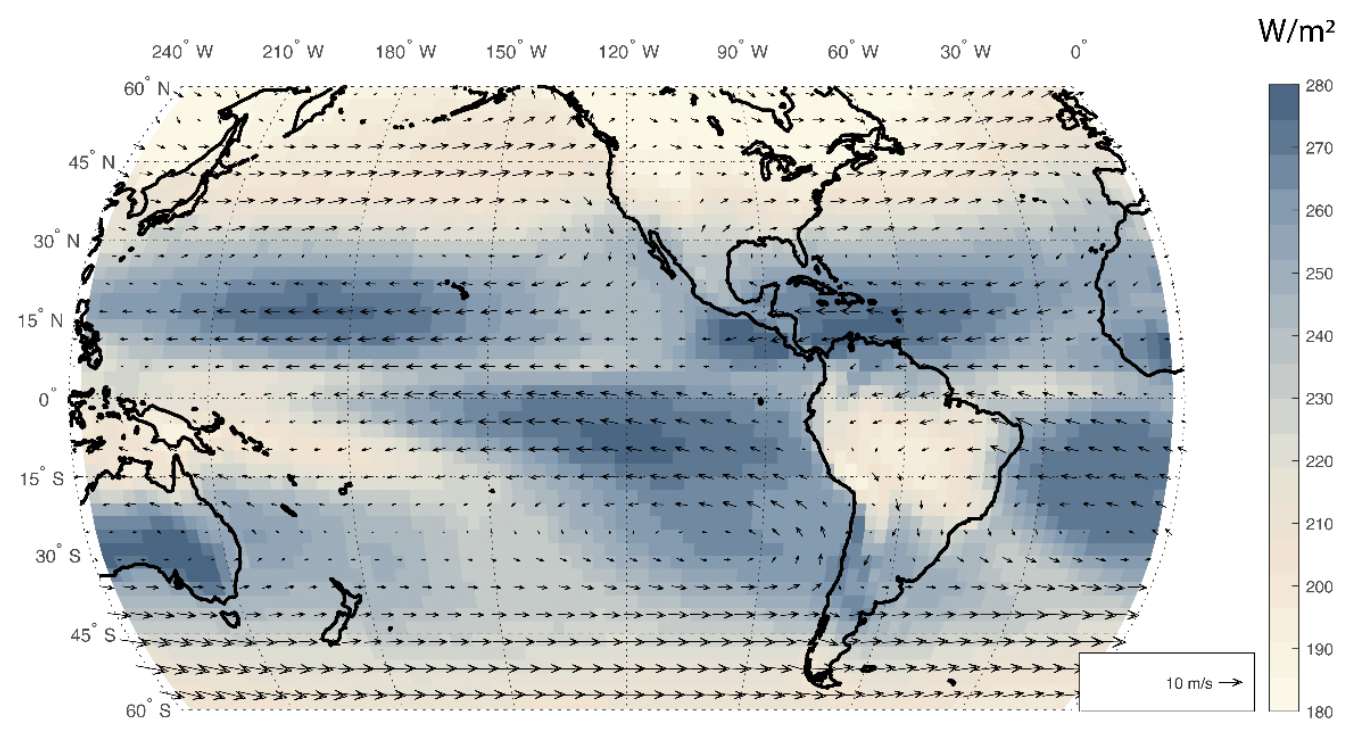

Figure 2. a) Climatological mean of omega vertical velocity (colors in Pa/s) and $200 \mathrm{hPa}$ winds (vectors) from ERA-Interim reanalysis for the period between 1990 to 2009. b) NOAA interpolated Outgoing Longwave Radiation from 1981 to 2010 in W/m2 (colors) and 850 hPa winds (vectors) from ERA-Interim (https://www.ecmwf.int/en/forecasts/datasets/reanalysis-datasets/era-interim). 
TM4-ECPL vs OMI/MLS mean 10/2004-12/2014
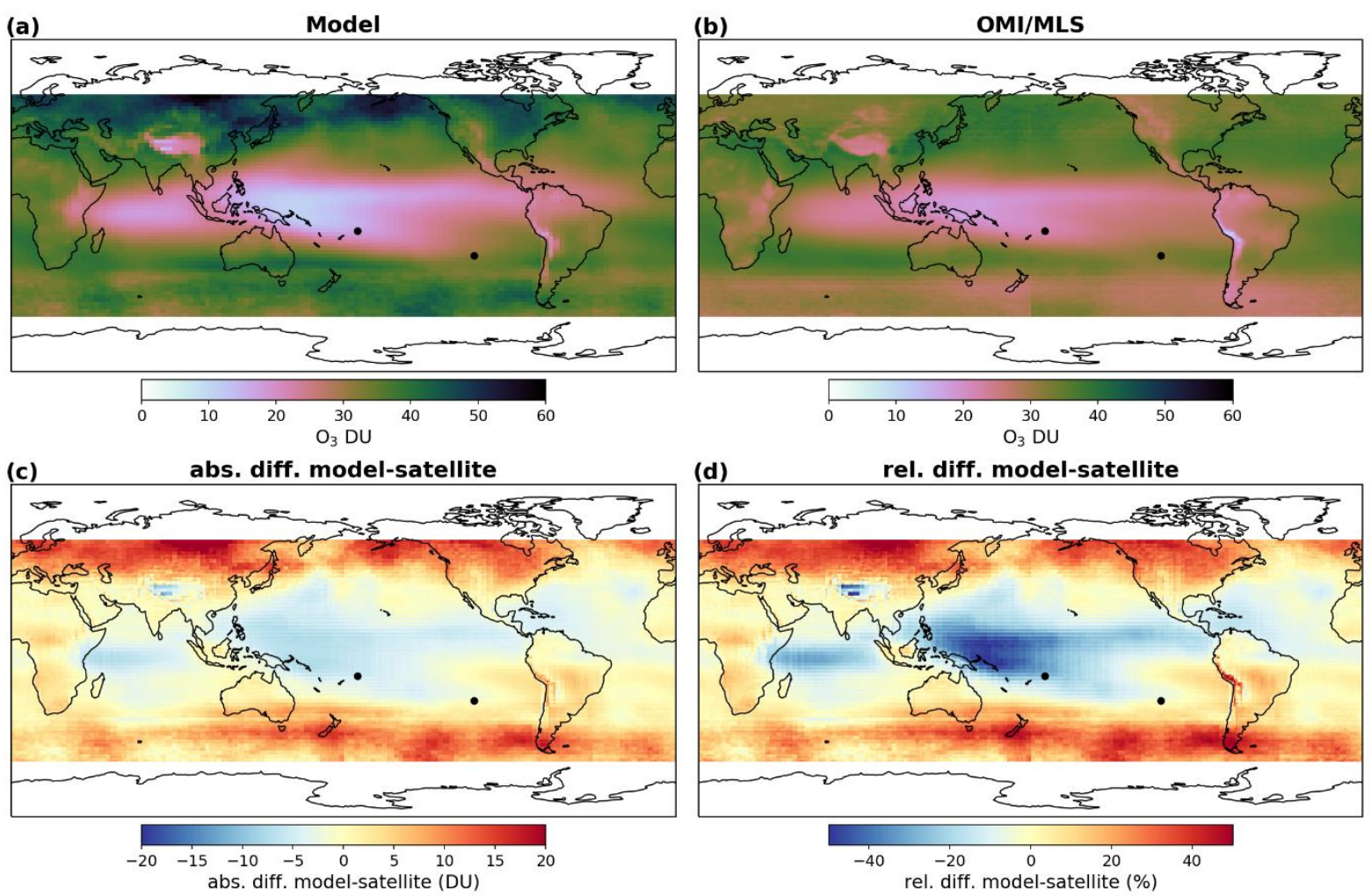

Figure 3. Model - Satellite comparison between TM4-ECPL and OMI/MLS mean tropospheric ozone column between October 2004 and December 2014. The top left panel shows the average modelled tropospheric ozone column for the period, the top right the average observed tropospheric ozone column, the bottom left is the absolute difference between model and satellite (DU) and the bottom right the relative difference $(\%)$ between model and satellite in the 1ox1.25o grid of OMI. 


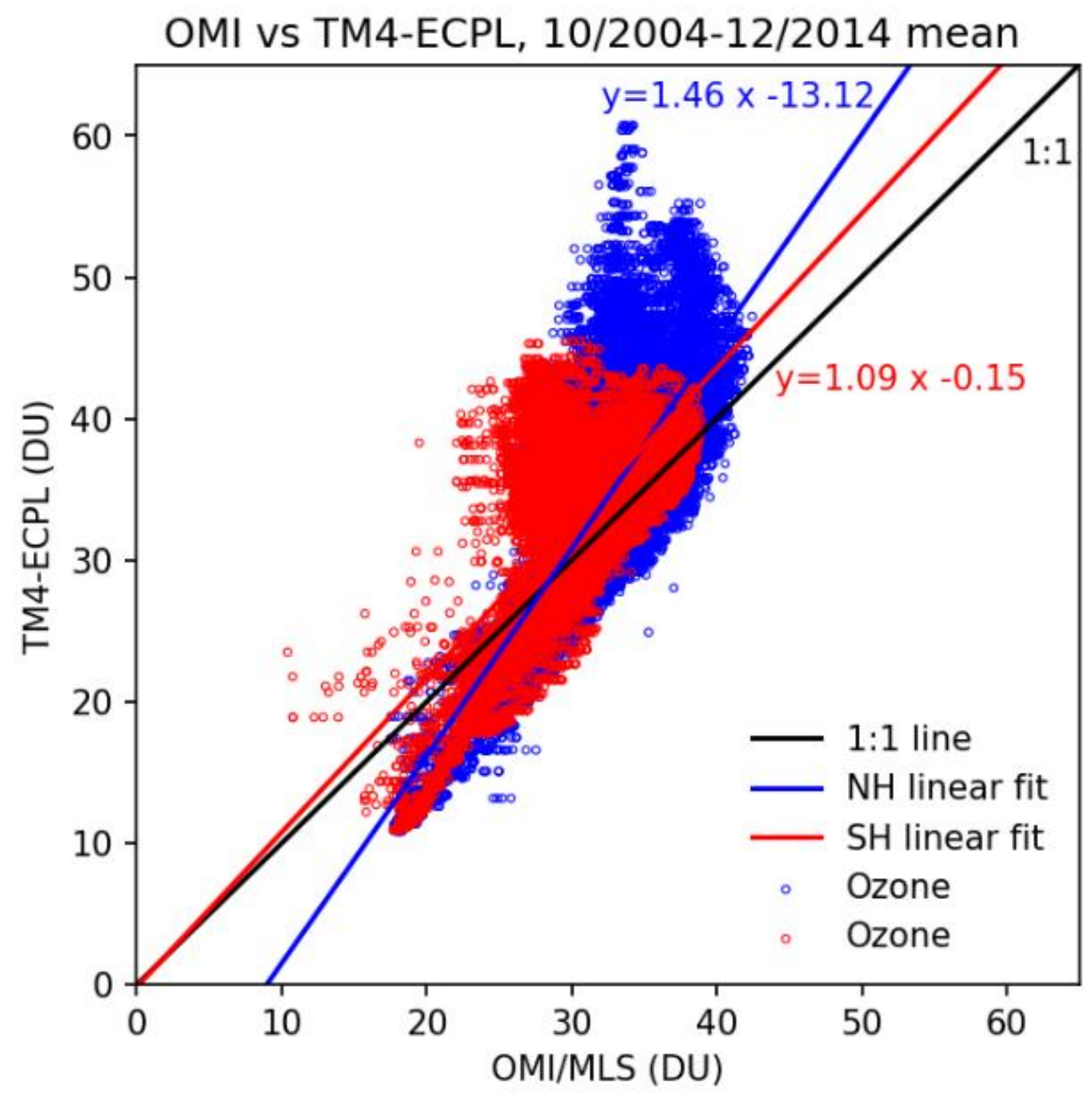

Figure 4. Mean tropospheric ozone column of model results versus observations (in DU) for the period between October 2004 and December 2014 for all grids cells of 1ox1.25o shown in Figure 3. Blue points are NH locations, red points are SH locations. The black line is the 1:1 line. The red line is the linear fit of all the SH data with the fit equation in red text, where the blue line is the linear fit of the NH data with the fit equation in blue text. 
TM4-ECPL vs MOPITT mean 2000-2014

(a) Model (satellite w/ AK and model as reality)

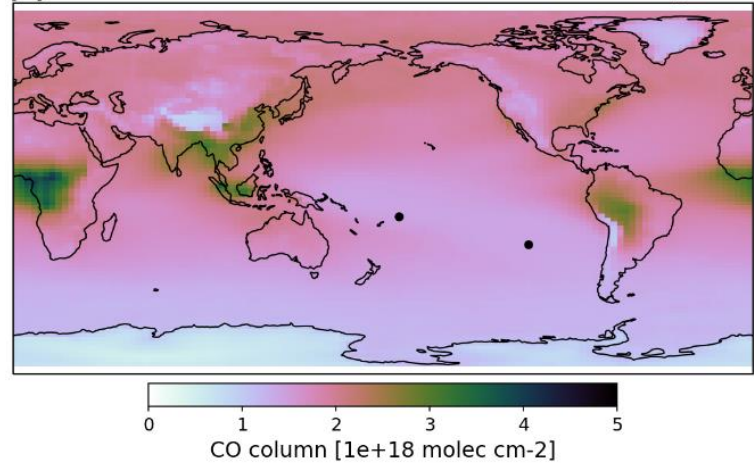

(c) abs. diff. model - satellite

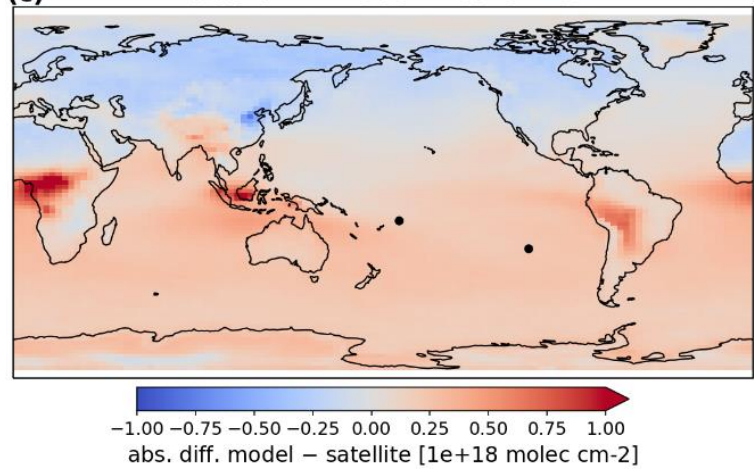

\section{(b) \\ Satellite (orig.)}

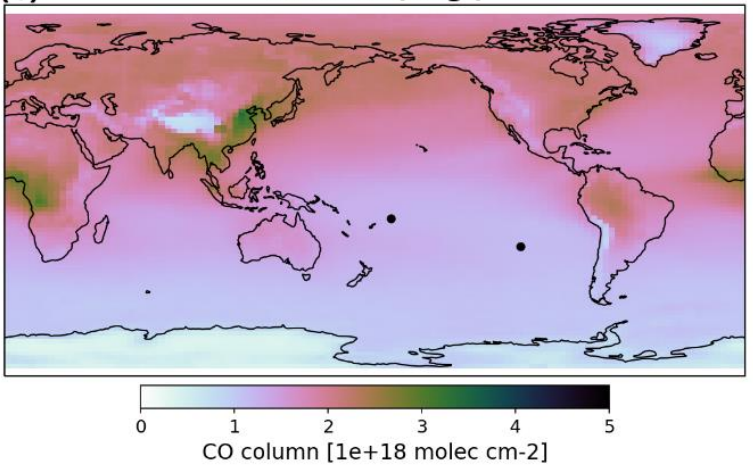

(d)

rel. diff. model - satellite

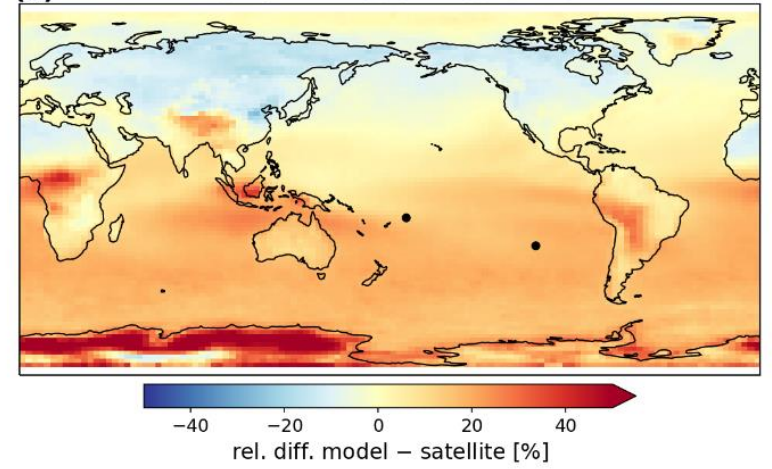

Figure 5. Model - Satellite comparison between TM4-ECPL and MOPITT for CO total columns averaged from 2000 to 2014 (in $1018 \mathrm{molec} / \mathrm{cm} 2$ ). (a) modelled data sampled following the satellite track and the overpass times and averaged over the period, (b) satellite data averaged over the period, (c) absolute difference (in $1018 \mathrm{molec} / \mathrm{cm} 2$ ) and (d) relative difference (in \%) between the mean values of model results and satellite in the $22 \mathrm{~km} \times 22 \mathrm{~km}$ grids of MOPITT. 
Timeseries of $\mathrm{O}_{3}$ for different altitudes at Samoa (left) and Rapa Nui (right)
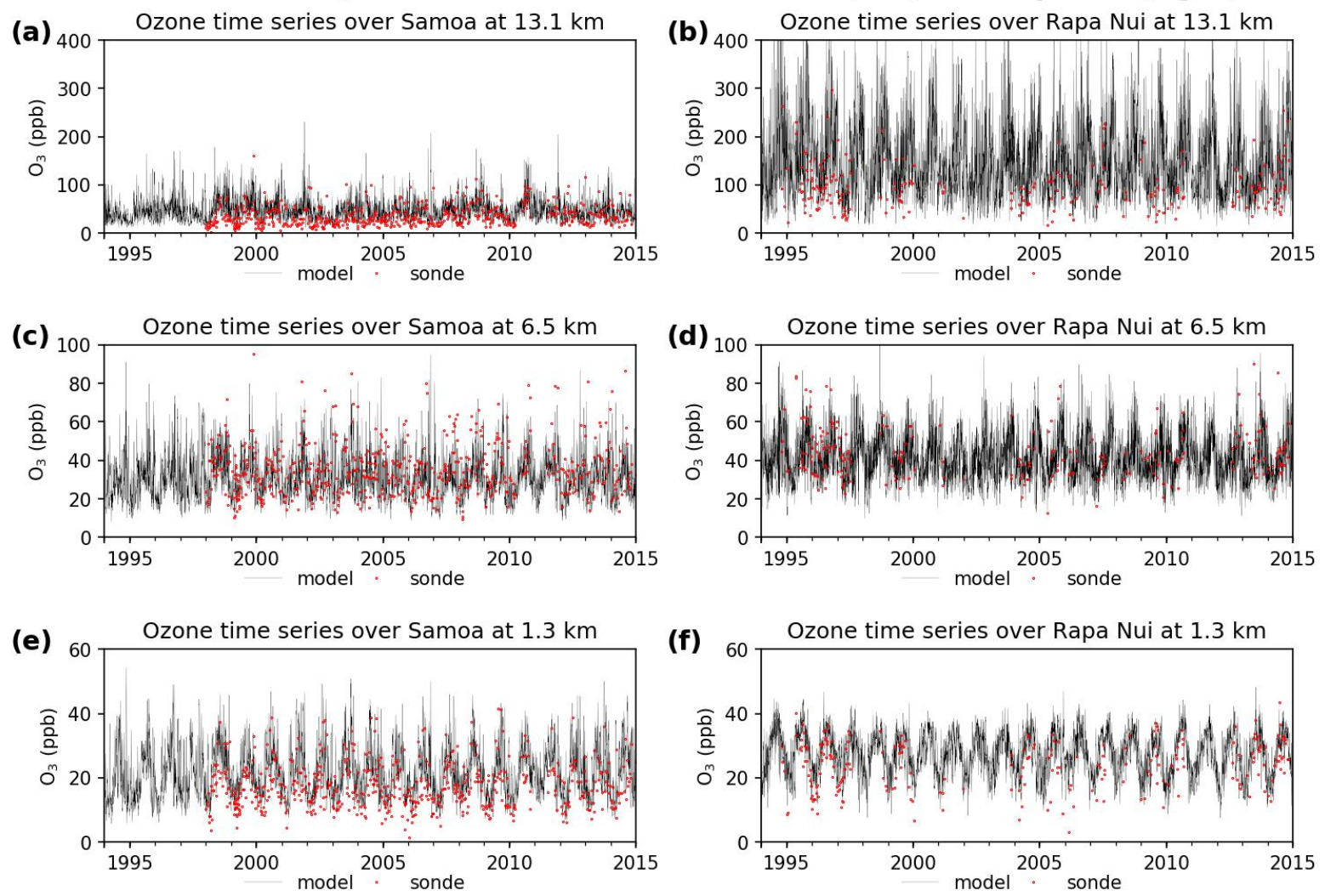

Figure 6. Time series of ozone in the boundary layer $(1.3 \mathrm{~km},(\mathrm{e})$ and (f)), mid-troposphere $(6.5 \mathrm{~km}$, (c) and (d)), and upper troposphere and lowers stratosphere $(13.1 \mathrm{~km},(\mathrm{a})$ and $(\mathrm{b}))$ as derived from the model (black lines) and ozonesonde measurements (red dots). Data correspond to the period between 1994 and 2014 at Samoa ((a,c,e)) and Rapa Nui (b,d,f). 


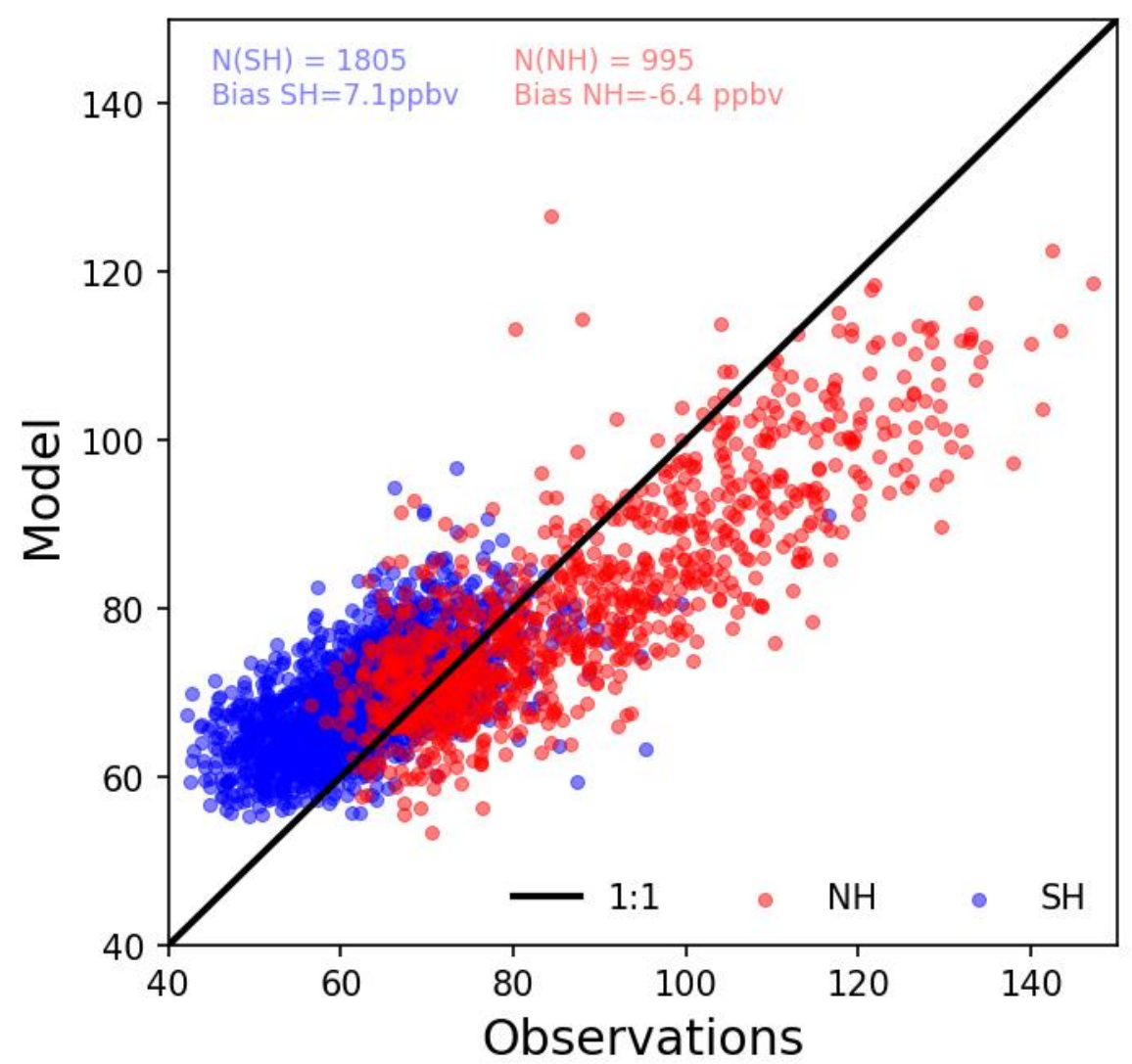

Figure 7. Comparison between monthly averages of simulated and observed surface CO at 14 stations in the Pacific (see Table 4). We show in blue stations in the Southern Hemisphere (SH), and in red stations in the Northern Hemisphere (NH) Also shown, are 

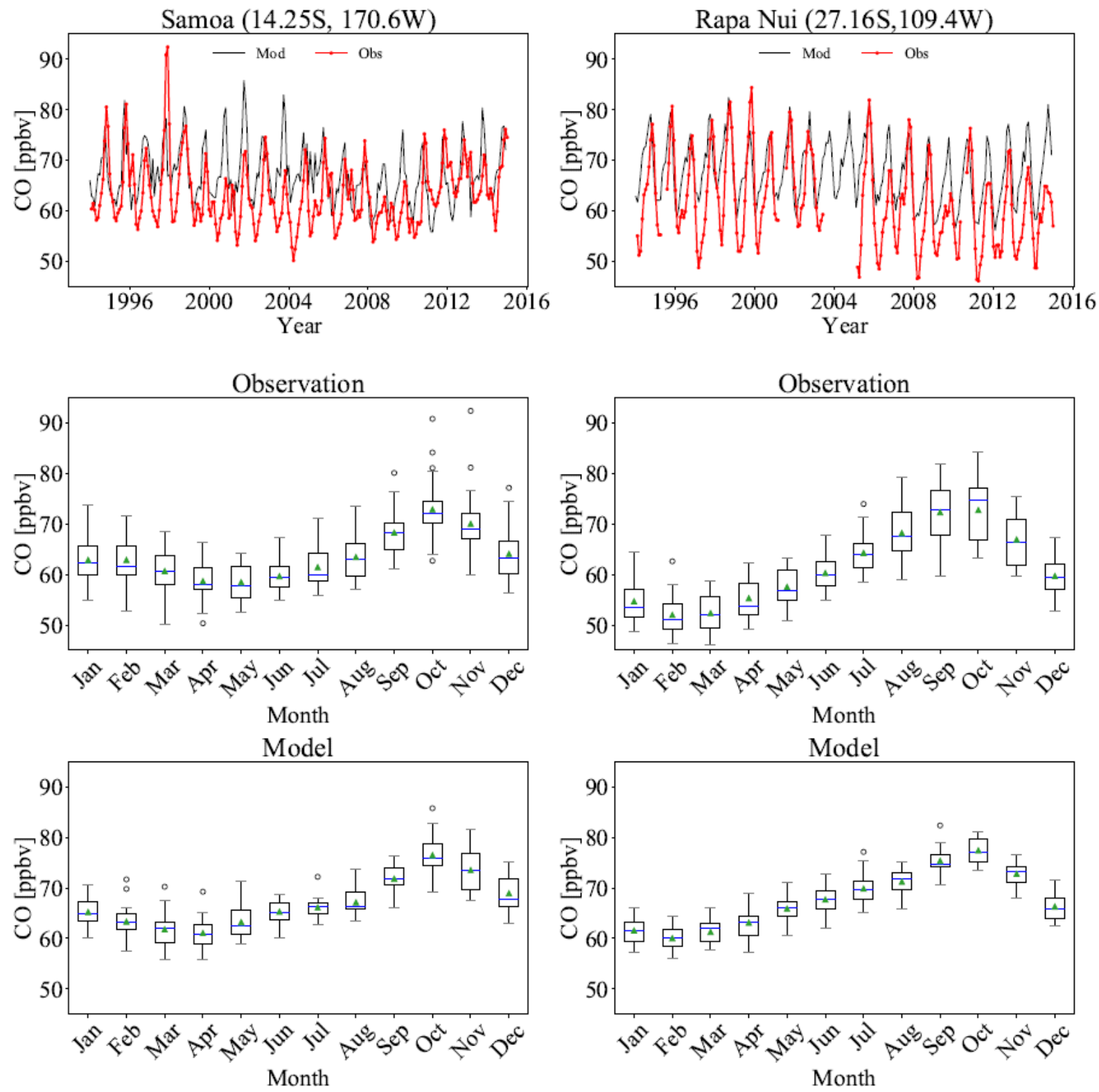

Figure 8. Timeseries (top row) of observed (red line) and simulated (blue line) CO volume mixing ratios for Samoa (left) and Rapa Nui (right). The seasonal variability is depictied in box plots as shown by observations (middle row) and the simulation (bottom row) for $\mathrm{CO}$ for the same stations. Whiskers show the 25 to 75 percentiles of the data. Circles show outliers, the green triangle is the average, and the blue line is the median of each monthly distribution. 

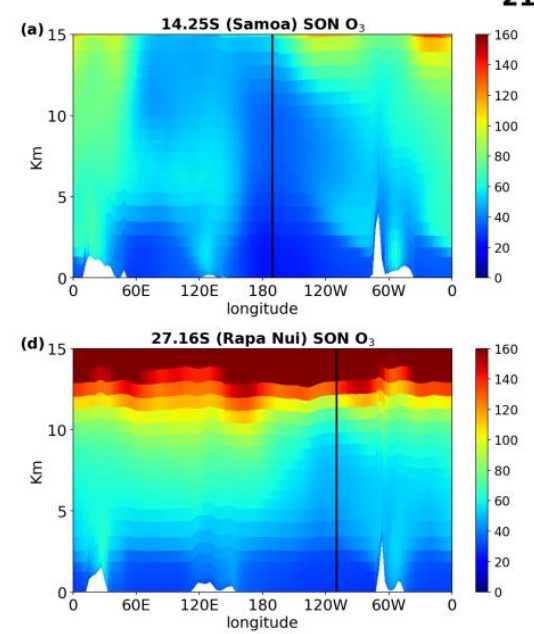

21 year mean September-October-November
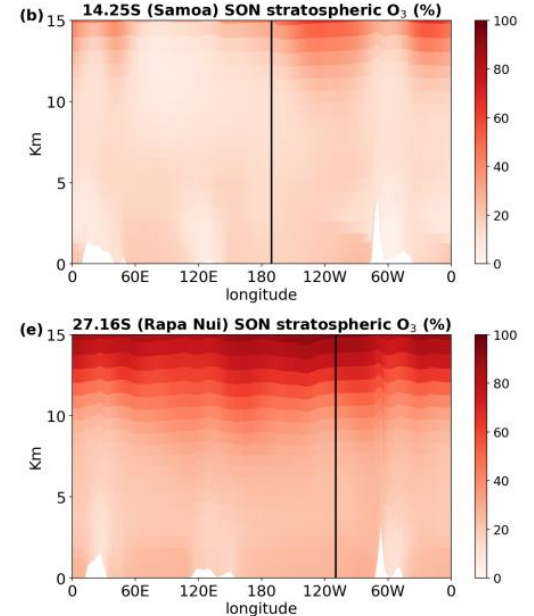
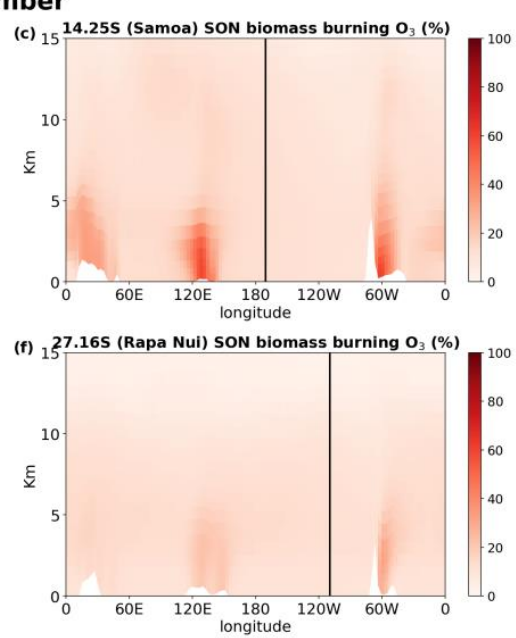

Figure 9. Cross-section of the 1994-2014 average atmospheric concentration of O3 at the latitude of Samoa (top) and Rapa Nui (bottom) for south hemispheric spring (September-October-November) as calculated by the TM4-ECPL. The left column shows the $\mathrm{O3}$ mixing ratio, the middle column shows the percentage of $\mathrm{O3}$ originating from the stratosphere and the right column the percentage contribution of biomass burning to the $\mathrm{O3}$ concentrations. The black vertical lines indicate the location of Samoa in the upper panels, and Rapa Nui in the lower panels. 
https://doi.org/10.5194/acp-2021-640

Preprint. Discussion started: 31 August 2021

(C) Author(s) 2021. CC BY 4.0 License.
Atmospheric

Chemistry

and Physics

Discussions
21 year mean March-April-May
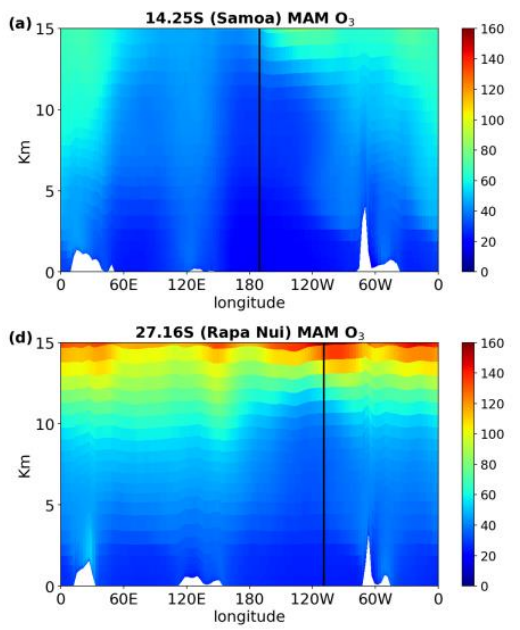

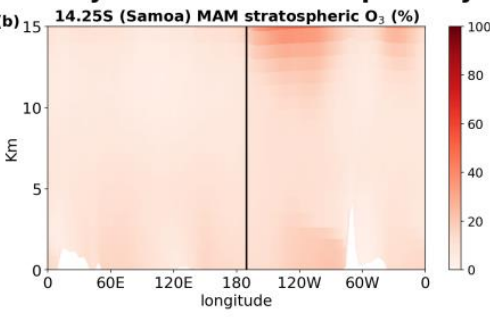

(e) $27.16 \mathrm{~S}$ (Rapa Nui) MAM stratospheric $\mathrm{O}_{3}(\%)$

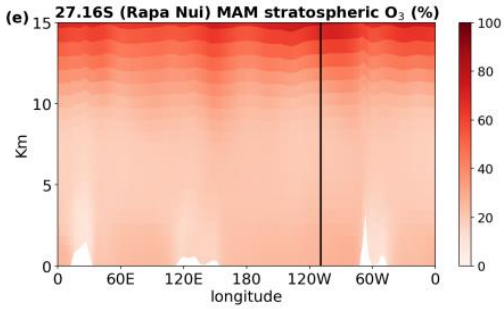

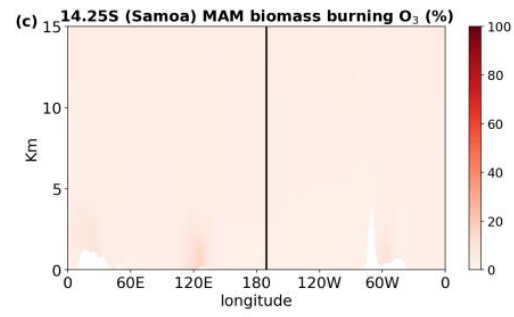

(f) 27.16S (Rapa Nui) MAM biomass burning $\mathrm{O}_{3}(\%)$

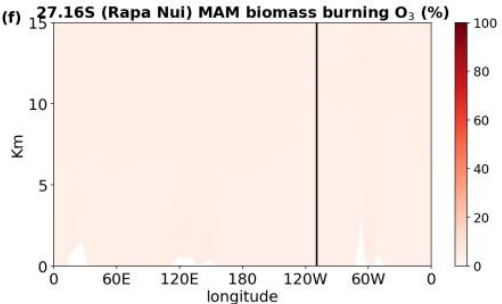

Figure 10. As in Figure 10, but for southern hemisphere autumn (March-April-May). 


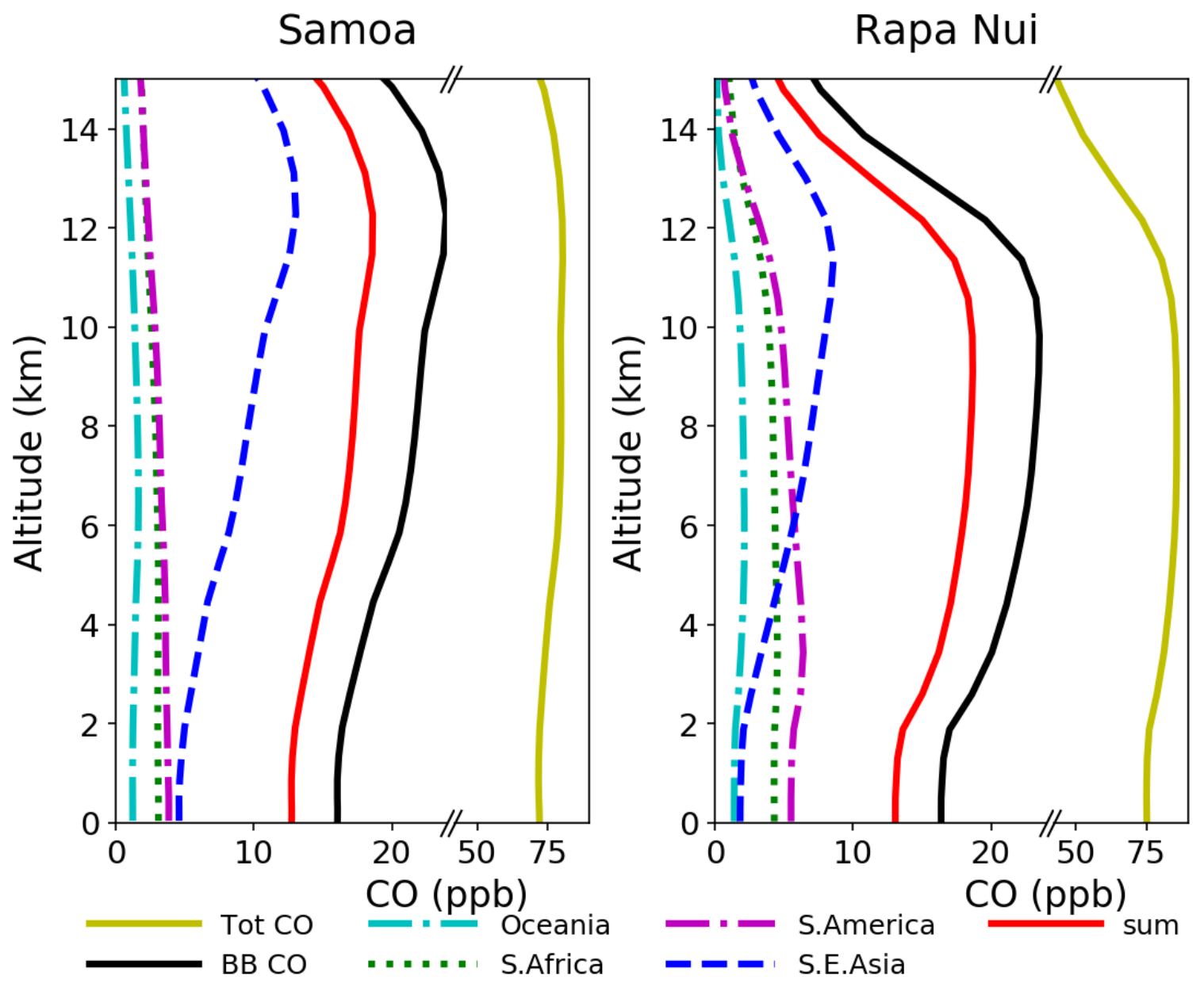

Figure 11. Vertical distribution of CO from different source regions (see legend) in Samoa (left) and Rapa Nui (right). Tot CO represents the contribution of all sources of $\mathrm{CO}$, whereas BB CO represents the sum of all shown biomass burning sources. The line in red (sum) indicates the sum of all individual BB contributions shown. 


\section{Impact of S. African fires to CO}
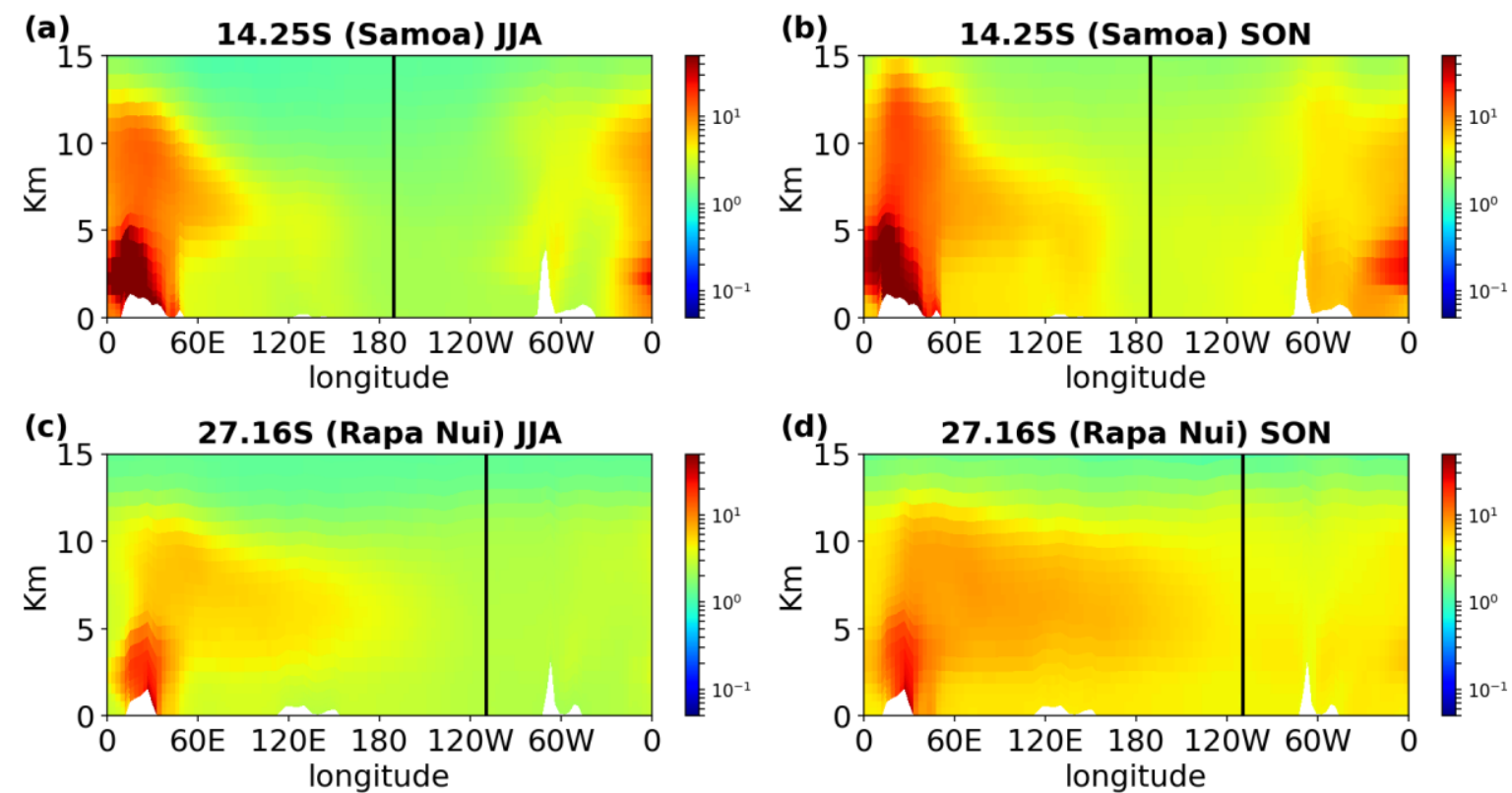

(e) JJA CO concentration @ $6.5 \mathrm{~km}$

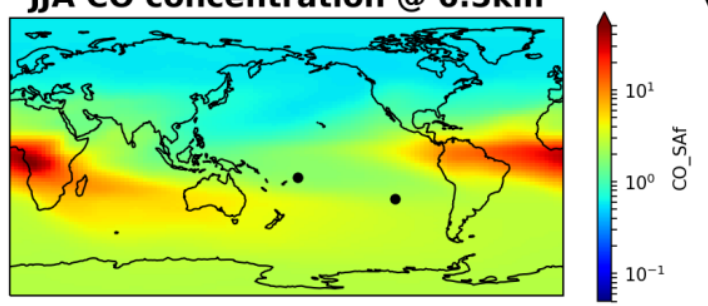

(f) SON CO concentration @ $6.5 \mathrm{~km}$

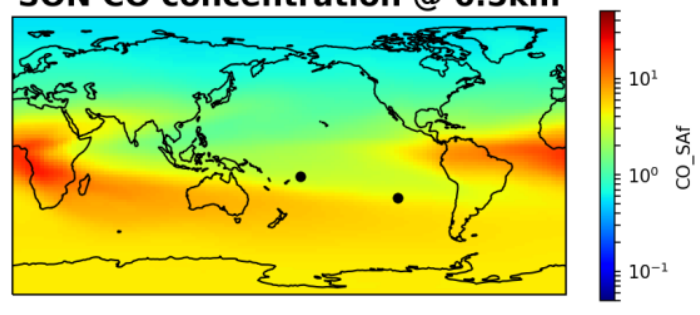

Figure 12. Impact of S. African fires to CO concentrations. a) JJA and b) SON 20 year mean impact at the cross-section of Samoa, c) JJA and d) SON at the cross-section of Rapa Nui. e) JJA. and f) SON horizontal distribution of the contribution at $6.5 \mathrm{~km}$ altitude 


\section{Impact of Oceanian fires to CO}
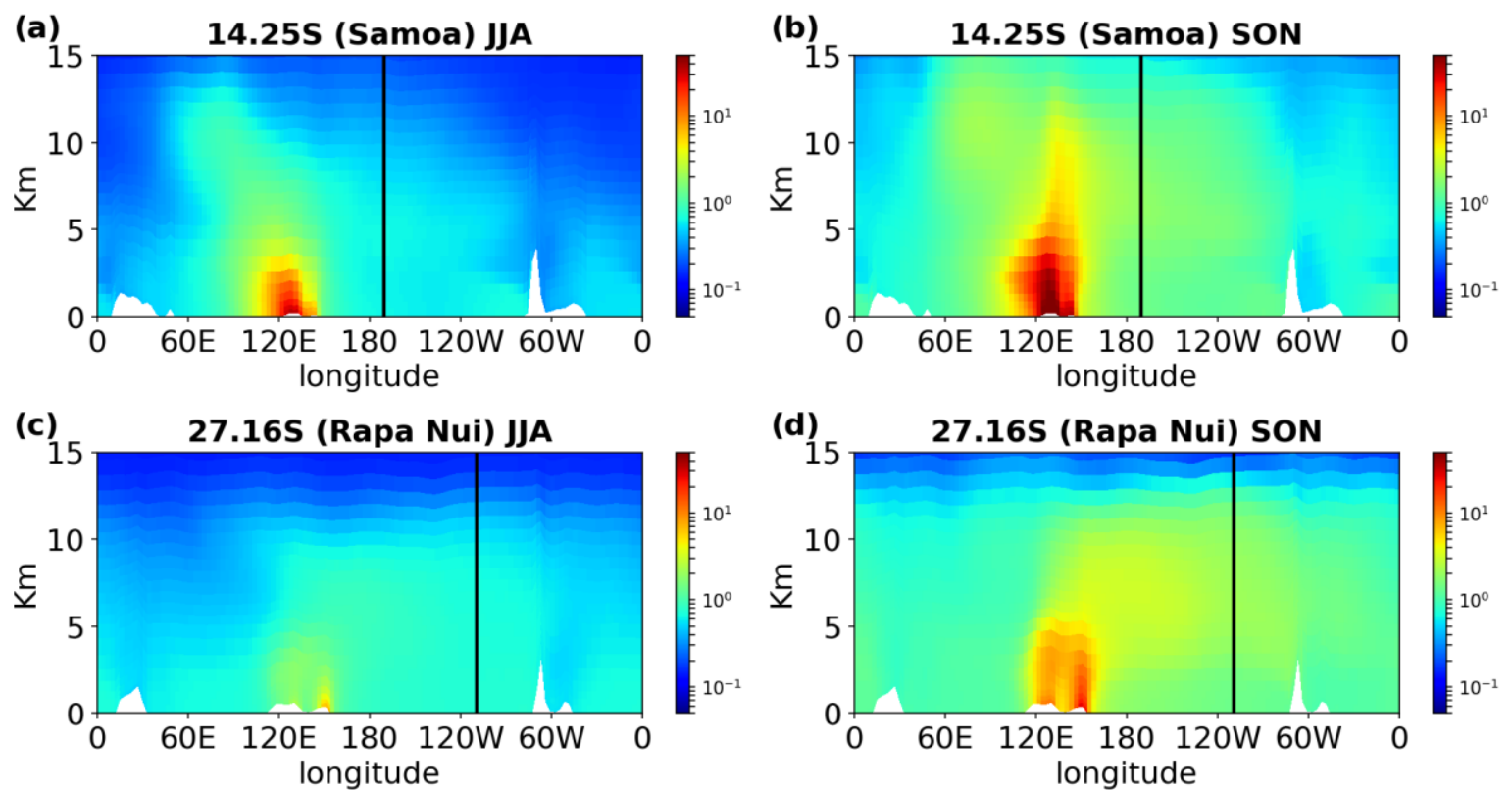

(e) JJA CO concentration @ $6.5 \mathrm{~km}$
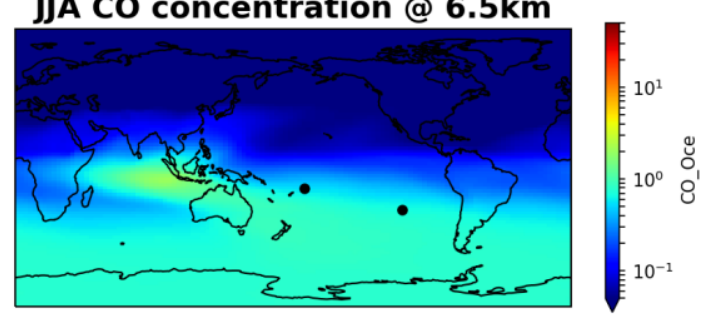

(f) SON CO concentration @ $6.5 \mathrm{~km}$

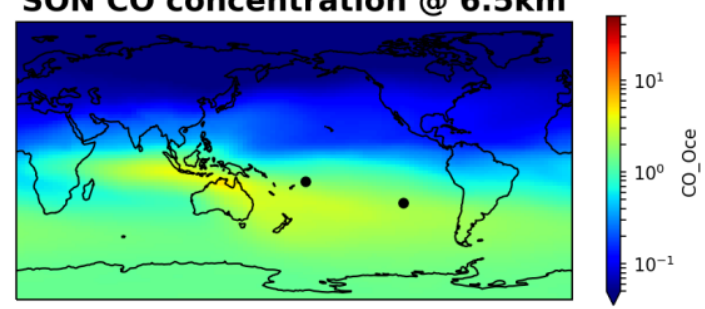

Figure 13. Impact of Oceanian fires to CO concentrations. a) JJA and b) SON 20 year mean impact at the cross-section of Samoa, 


\section{Impact of S. American fires to CO}
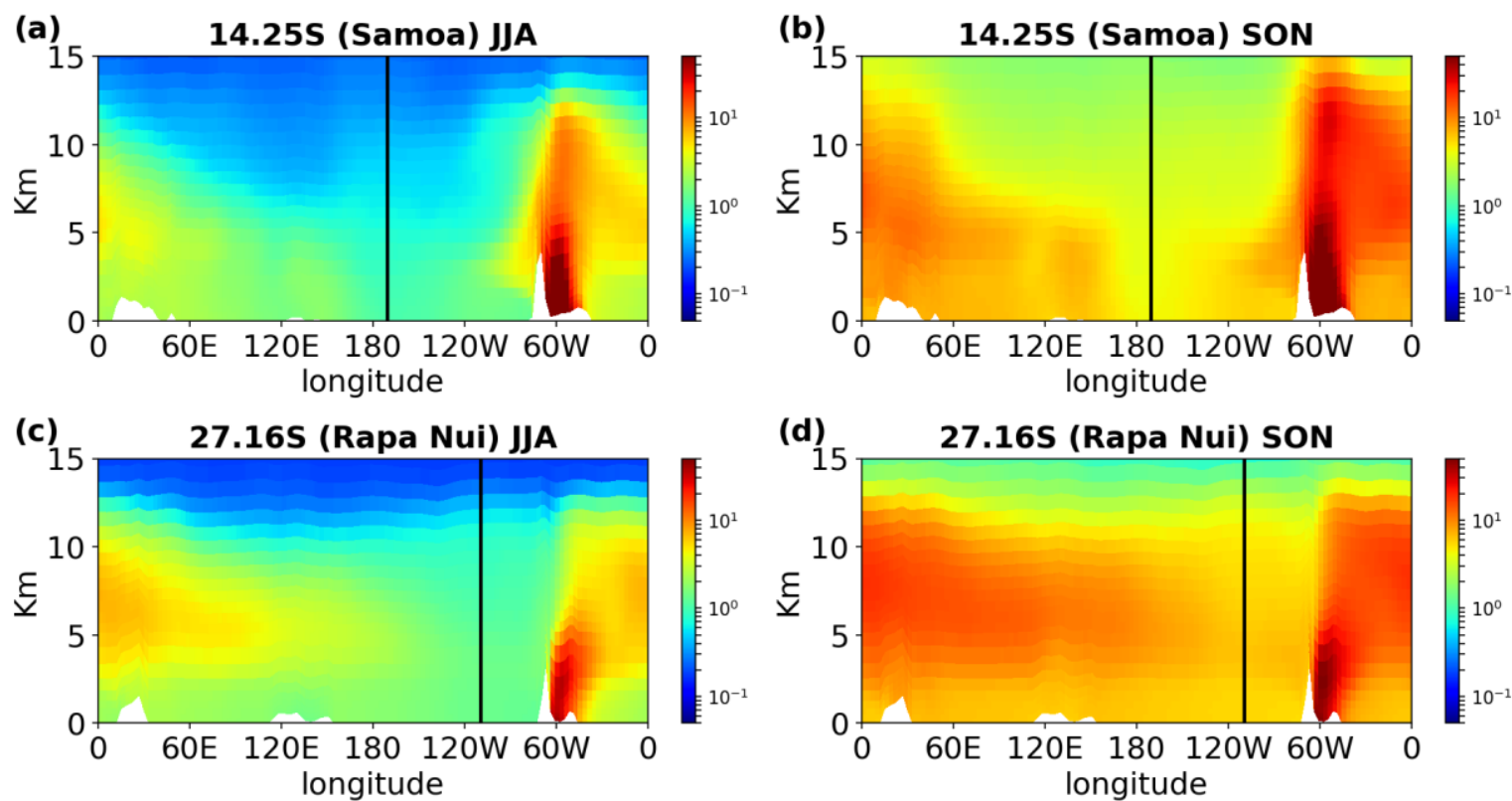

(e) JJA CO concentration @ 6.5km
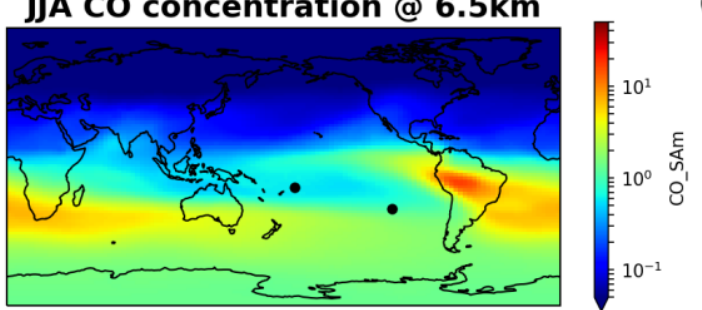

(f) SON CO concentration @ $6.5 \mathrm{~km}$

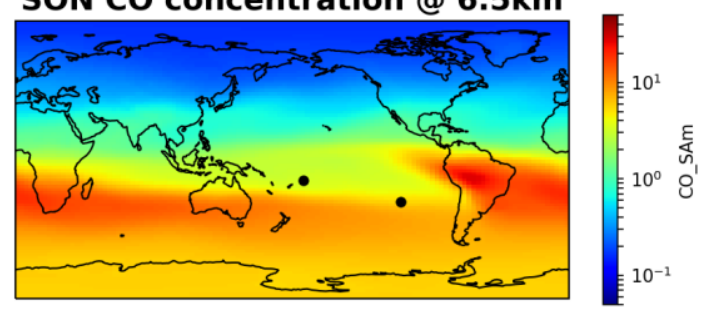

Figure 14. Impact of S. American fires to CO concentrations. a) JJA and b) SON 20 year mean impact at the cross-section of Samoa, c) JJA and d) SON at the cross-section of Rapa Nui. e) JJA. and f) SON horizontal distribution of the contribution at $6.5 \mathrm{~km}$ altitude 


\section{Impact of S. E. Asian fires to CO}
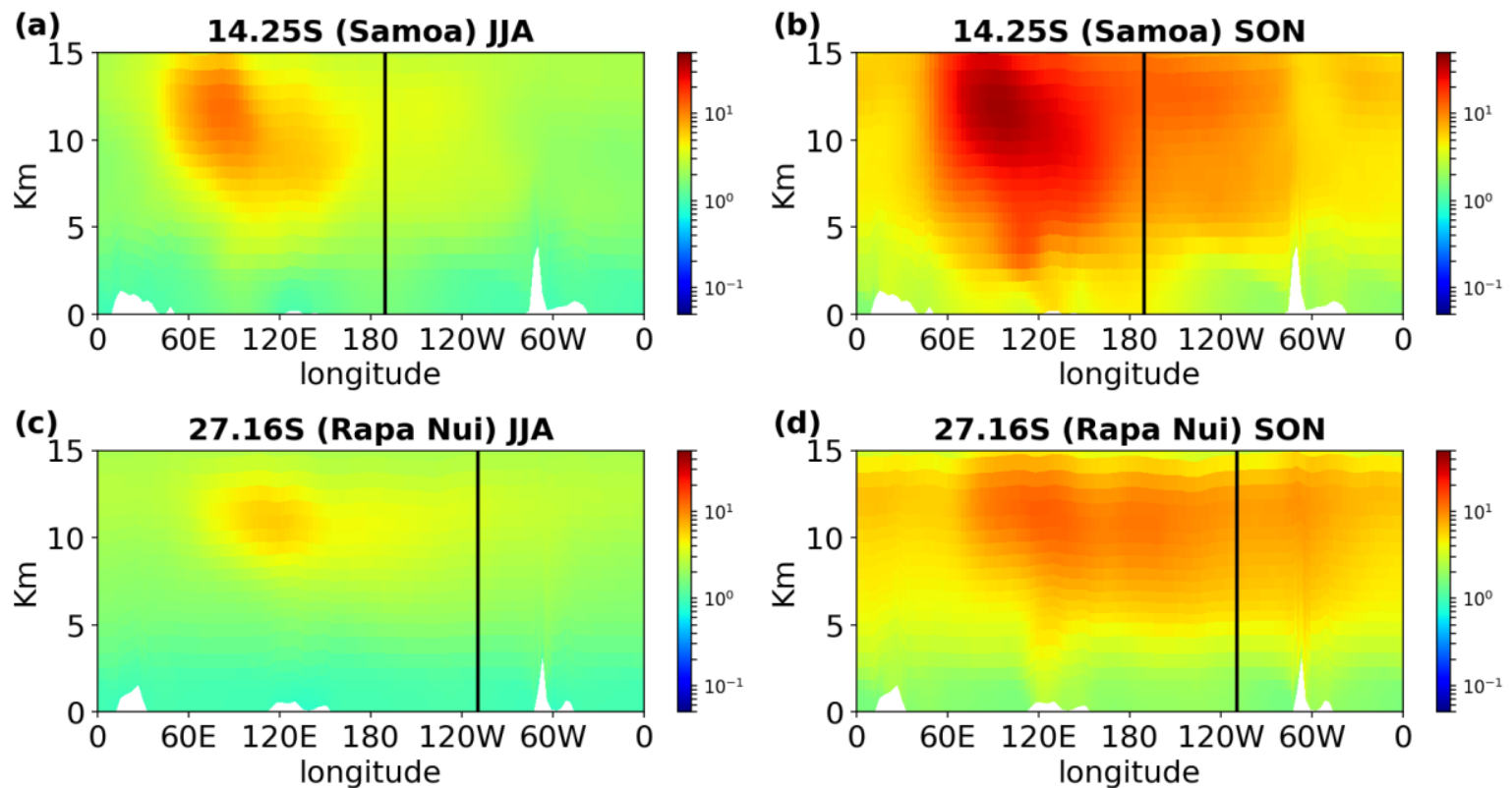

(e) JJA CO concentration @ $6.5 \mathrm{~km}$

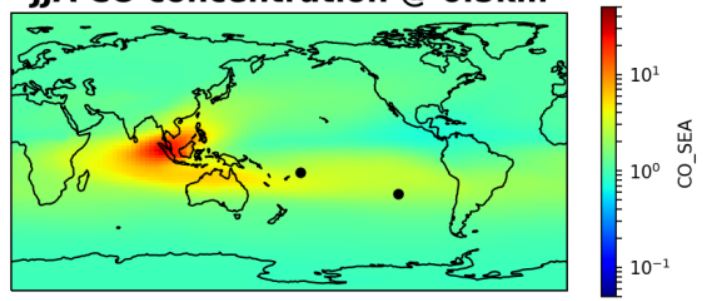

(f) SON CO concentration @ $6.5 \mathrm{~km}$

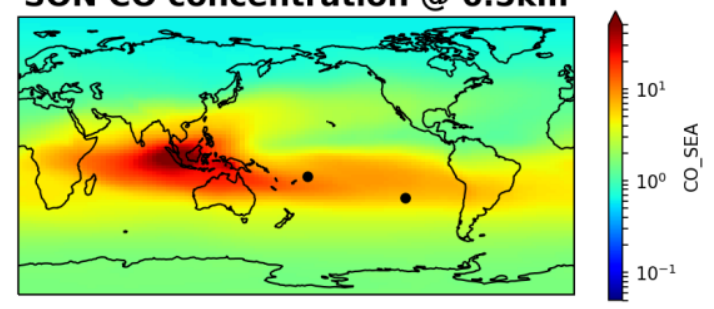

Figure 15. Impact of S. E. Asian fires to CO concentrations. a) JJA and b) SON 20 year mean impact at the cross-section of Samoa, c) JJA and d) SON at the cross-section of Rapa Nui. e) JJA. and f) SON horizontal distribution of the contribution at $6.5 \mathrm{~km}$ altitude 